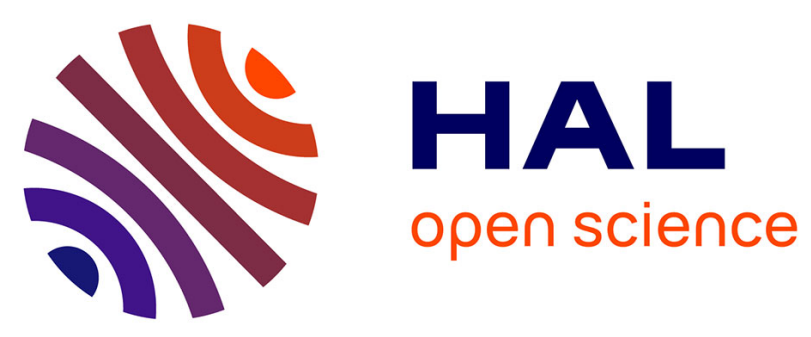

\title{
Serotonin Modulates Developmental Microglia via 5-HT2B Receptors: Potential Implication during Synaptic Refinement of Retinogeniculate Projections.
}

M Kolodziejczak, C Béchade, N Gervasi, T Irinopoulou, Sm Banas, C Cordier, A Rebsam, A Roumier, Luc Maroteaux

\section{To cite this version:}

M Kolodziejczak, C Béchade, N Gervasi, T Irinopoulou, Sm Banas, et al.. Serotonin Modulates Developmental Microglia via 5-HT2B Receptors: Potential Implication during Synaptic Refinement of Retinogeniculate Projections.. ACS Chemical Neuroscience, 2015, 6 (7), pp.1219-1230. 10.1021/cn5003489 . hal-01224546

\section{HAL Id: hal-01224546 \\ https://hal.science/hal-01224546}

Submitted on 18 Feb 2016

HAL is a multi-disciplinary open access archive for the deposit and dissemination of scientific research documents, whether they are published or not. The documents may come from teaching and research institutions in France or abroad, or from public or private research centers.
L'archive ouverte pluridisciplinaire HAL, est destinée au dépôt et à la diffusion de documents scientifiques de niveau recherche, publiés ou non, émanant des établissements d'enseignement et de recherche français ou étrangers, des laboratoires publics ou privés. 
This document is confidential and is proprietary to the American Chemical Society and its authors. Do not copy or disclose without written permission. If you have received this item in error, notify the sender and delete all copies.

\section{Serotonin modulates developmental microglia via 5-HT2B receptors: potential implication during synaptic refinement of retinogeniculate projections.}

\begin{tabular}{|r|l|}
\hline \multicolumn{1}{|c|}{ Journal: } & ACS Chemical Neuroscience \\
\hline Manuscript ID: & cn-2014-003489.R3 \\
\hline Manuscript Type: & Article \\
\hline Date Submitted by the Author: & $\mathrm{n} / \mathrm{a}$ \\
\hline Complete List of Authors: & $\begin{array}{l}\text { Kolodziejczak, Marta; INSERM UMR S839, Université Pierre et Marie Curie } \\
\text { Béchade, Catherine; INSERM UMR S839, Université Pierre et Marie Curie } \\
\text { Gervasi, Nicolas; INSERM UMR S839, Université Pierre et Marie Curie } \\
\text { Irinopoulou, Theano; INSERM UMR S839, Université Pierre et Marie Curie } \\
\text { Banas, Sophie; INSERM UMR S839, Université Pierre et Marie Curie } \\
\text { Cordier, Corinne; INSERM US24, Paris Descartes University } \\
\text { Rebsam, Alexandra; INSERM UMR S839, Université Pierre et Marie Curie } \\
\text { Roumier, Anne; INSERM UMR S839, Université Pierre et Marie Curie } \\
\text { Maroteaux, Luc; INSERM UMR S839, Université Pierre et Marie Curie }\end{array}$ \\
\hline \hline
\end{tabular}


Title. Serotonin modulates developmental microglia via 5-HT ${ }_{2 B}$ receptors: potential implication during synaptic refinement of retinogeniculate projections.

\author{
Author List. Marta Kolodziejczak, Catherine Béchade, Nicolas Gervasi, Theano Irinopoulou, \\ Sophie M. Banas, Corinne Cordier $\$$, Alexandra Rebsam, Anne Roumier* and Luc \\ Maroteaux* \\ INSERM UMR-S 839, F75005, Paris, France; Sorbonne Universités, UPMC Univ Paris06, \\ F75005, Paris; Institut du Fer à Moulin, F75005, Paris. \\ $\$$ Cytometry facility, INSERM US24, F75005, Paris; CNRS UMS 3633 Paris Descartes \\ University, F75005, Paris. \\ *Co-corresponding authors : \\ Luc Maroteaux, $\quad$ Email : luc.maroteaux@upmc.fr; Tel: (33) 0145876123 \\ Anne Roumier $\quad$ Email : anne.roumier@inserm.fr Tel: (33) 0145876124 \\ Institut du Fer à Moulin UMR-S839 INSERM/UPMC 17 rue du Fer à Moulin 75005 Paris \\ Fax: (33) 0145876132
}

\begin{abstract}
.
Maturation of functional neuronal circuits during central nervous system development relies on sophisticated mechanisms. First, axonal and dendritic growth should reach appropriate targets for correct synapse elaboration. Second, pruning and neuronal death are required to eliminate redundant or inappropriate neuronal connections. Serotonin, in addition to its role as a neurotransmitter, actively participates in postnatal establishment and refinement of brain wiring in mammals. Brain resident macrophages, i.e. microglia, also play an important role in developmentally-regulated neuronal death as well as in synaptic maturation and elimination. Here, we tested the hypothesis of cross-regulation between microglia and serotonin during postnatal brain development in a mouse model of synaptic refinement. We found expression of the serotonin $5-\mathrm{HT}_{2 \mathrm{~B}}$ receptor on postnatal microglia, suggesting that serotonin could participate in temporal and spatial synchronization of microglial functions. Using two-photon microscopy, acute brain slices and local delivery of serotonin, we observed that microglial processes moved rapidly toward the source of serotonin in $\mathrm{Htr}_{2 B}{ }^{+/+}$mice, but not in $\mathrm{Htr}_{2 B}{ }^{-/}$ mice lacking the 5- $\mathrm{HT}_{2 \mathrm{~B}}$ receptor. We then investigated whether some developmental steps known to be controlled by serotonin, could potentially result from microglia sensitivity to serotonin. Using an in vivo model of synaptic refinement during early brain development, we investigated the maturation of the retinal projections to the thalamus and observed that $\mathrm{Htr}_{2 B}{ }^{-1-}$ mice present anatomical alterations of the ipsilateral projecting area of retinal axons into the thalamus. In addition, activation markers were upregulated in microglia from $\mathrm{Htr}_{2 B}{ }^{-/}$ compared to control neonates, in the absence of apparent morphological modifications. These results support the hypothesis that serotonin interacts with microglial cells and these interactions participate in brain maturation.
\end{abstract}

\title{
Keywords.
}

Microglia; mice; postnatal development; retinal projections; serotonin receptors; thalamus. 
Introduction.

Recent evidence indicates that brain resident macrophages, microglial cells, are essential for the proper wiring of neuronal networks at postnatal periods ${ }^{1,2}$. The critical process of developmental elimination of inappropriate synapses involves the phagocytic activity of microglia ${ }^{3,4}$, however, the influence of microglial cells on synapse development most likely extends beyond their phagocytic capabilities. These cells indeed release a large array of signaling molecules, including cytokines, growth factors and transmitters which modulate synaptic functions in pathological conditions 5 . In physiological conditions, microglial cells were recently shown to modulate synapse formation ${ }^{6}$ and activity ${ }^{7}$, and thus to shape neuronal circuits ${ }^{8}$. However, mediators controlling the activity of microglia in order to achieve these functions remain largely unknown.

Unlike all other brain cell types, microglial cells have a myeloid origin and derive from precursors produced by primitive hematopoiesis in the yolk sac. Microglial precursors start invading the embryonic brain shortly after blood circulation is established. In mice, the first microglia can be detected in the developing brain from embryonic day (E) $9.5^{9}$. The microglia invasion is a complex process and a recent study provided some insight into microglia colonization of the mouse cortex, from E11.5 to E17.5 ${ }^{10}$. These precursor cells have an amoeboid phenotype ${ }^{11}$ and accumulate at several sites (e.g. at plexus choroid and corpus callosum) from where they start invading the brain parenchyma. Until postnatal day (P)5, higher densities of microglia are observed in the vicinity of meninges and ventricular surfaces, whereas there are fewer microglia in cortical layers ${ }^{12}$. The gradual increase in microglia density is explained by both the migration of the microglial precursors and by microglial cell proliferation, which are necessary in order to reach adult levels ${ }^{12}$. Early postnatal microglia share similarities with both ramified and activated microglia and some P5-P9 microglia express CD68, a lysosomal marker specific to phagocytic-activated microglia, which is downregulated in adult P30 microglia ${ }^{4}$. Similarly, electrophysiological studies in mouse cortex have revealed that the population of early postnatal microglia presents a transient outward rectifying current above $-30 \mathrm{mV}$ mediated by Kv1.3 potassium channels, similar to activated microglia, however, these postnatal microglia do not express other known activation markers like Mac2 or MHCII ${ }^{12}$. Additionally, these microglial cells also express a panel of specific markers including purinergic receptors 10,12 .

The mouse retinogeniculate system is a classic model for studying developmental synapse elimination. Early in postnatal development, retinal ganglion cells (RGCs) form transient functional synaptic connections with relay neurons in the dorsal lateral geniculate nucleus (dLGN) 13, 14. Before eye opening around P14, many of these transient retinogeniculate synapses are eliminated, while the remaining synaptic arbors are elaborated and strengthened in a common pathway to refine synaptic circuits. Notably, microglial engulfment of retinogeniculate inputs occurs during the narrow window of postnatal development (P5-P9) ${ }^{4}$. In mice, dLGN in each side of the brain contains axonal terminals from both eyes. In a mature/adult dLGN, the contralateral fibers occupy most of its territory except for a small gap containing exclusively fibers from the ipsilateral eye. In contrast to the adult situation, at $\mathrm{P} 3$, the segregation between ipsilateral and contralateral retinal projections is not yet present and RGC axonal projections from each eye are intermingled in the dLGN; the ipsilateral projections are diffuse and the contralateral fibers occupy the entire dLGN ${ }^{15}$. This is due to an excessive number of synaptic connections. During the first two postnatal weeks, a maturation period characterized by a massive synaptic pruning, the redundant synapses are eliminated and the correct connections are strengthened resulting in a segregated phenotype ${ }^{16}$. Pruning of pre- and post-synaptic elements by microglia has been observed in the developing hippocampus where the neuron-to-microglia fractalkine signaling pathway controls the number of synapses possibly by recruiting microglia in the hippocampus ${ }^{3}$. In 
physiological conditions, microglial cells modulate synaptic activity or stability ${ }^{7,8,17,18}$. During the mouse somato-sensory cortex development, fractalkine-dependent recruitment of microglial cells may influence synapse functional maturation ${ }^{19}$. In the developing dLGN, the appropriate segregation of eye-specific axonal projections requires microglial cells expressing the complement receptor 3 (CR3), which phagocytose presynaptic elements tagged by complement proteins $\mathrm{C} 1 \mathrm{q}$ and $\mathrm{C} 3{ }^{4,20}$.

Interestingly, eye-specific segregation of retinal projections in the thalamus also depends on an appropriate serotonin (5-Hydroxytryptamine, 5-HT) level. Segregation of ipsilateral and contralateral regions in dLGN does not occur properly in mice lacking the gene encoding monoamine oxidase A (MAOA) or serotonin transporter (SERT), both mice exhibiting an increased 5-HT level ${ }^{16,21-23}$. Thus, an increased 5-HT level has been proposed to alter activity-dependent segregation mechanisms. The early appearance of brain 5-HT and its heterologous uptake during critical periods of development, suggest the importance of this monoamine during early steps of brain development and wiring. An in situ study has reported that 5-HT increases microglia motility toward a laser injury and decreases phagocytic capacities of amoeboid microglia on acute brain slices ${ }^{24}$. Although expression of a number of 5 -HT receptors has been detected on microglial cells ${ }^{24}$, the contribution of specific 5-HT receptors is not yet known. Integrating the participation of both microglia and 5-HT in segregation of eye-specific RGC projections, it was interesting to evaluate the putative participation of $5-\mathrm{HT}_{2 \mathrm{~B}}$ receptors since (i) peripheral macrophages have been shown to express $5-\mathrm{HT}_{2 \mathrm{~B}}$ receptors ${ }^{25}$; (ii) the phenotype of mice lacking $5-\mathrm{HT}_{2 \mathrm{~B}}$ receptors includes neurodevelopmental-like disorders ${ }^{26}$. (iii) $5-\mathrm{HT}_{2 \mathrm{~B}}$ receptors have been implicated in exosome secretion by microglia ${ }^{27}$; and (iv) $5-\mathrm{HT}_{2 \mathrm{~B}}$ receptors participate in hematopoietic precursors differentiation especially of the myeloid lineage ${ }^{28}$.

In this work, we assessed putative 5-HT/microglia interactions during the brain wiring critical period focusing on the putative implication of $5-\mathrm{HT}_{2 \mathrm{~B}}$ receptor in refinement of retinal projections in the thalamus in the dLGN area. We first describe expression of $5-\mathrm{HT}_{2 \mathrm{~B}}$ receptors by postnatal microglia and close appositions of serotonergic varicosities with microglial processes. Then, we show that microglial processes can move rapidly toward a source of 5-HT in $\mathrm{Htr}_{2 B}{ }^{+++}$mice, but not in $\mathrm{Htr}_{2 B}{ }^{-\mathrm{-}}$ mice lacking the 5- $\mathrm{HT}_{2 \mathrm{~B}}$ receptor. Additionally, activation markers are upregulated in microglia from $\mathrm{Htr}_{2 B}{ }^{-/-}$mice. In the in vivo model of dLGN synaptic refinement during early brain development, we found that $\mathrm{Htr}_{2 B}{ }^{-1}$ mice demonstrate anatomical alterations of the projecting area of retinal projections into the thalamus. We, therefore, conclude that 5-HT interacts with microglial cells and that these interactions could participate in postnatal brain maturation. 
Results and Discussion.

Postnatal microglia express 5-HT ${ }_{2 B}$ receptors and are in close vicinity of 5-HT fibers.

Although a recent paper identified the presence of 5-HT receptors on primary cultures of microglia from neonatal brains ${ }^{24}$, there is very little information on 5-HT receptor functional expression in neonatal microglia in vivo. We first confirmed by RT-PCR the 5-HT receptor mRNA expression in primary cultures of pure microglia obtained from neonatal brains. The results identified mainly the presence of $\mathrm{Htr}_{2 B}$ mRNA coding for the 5- $\mathrm{HT}_{2 \mathrm{~B}}$ receptor in cultured microglia (Fig. 1A). The transcript for $H_{t r}{ }_{2 A}$ was also detected, but its expression was much weaker (confirmed by qPCR, data not shown). Other 5-HT receptor expression could easily be detected in whole hippocampus both at P0 and P30, but not in microglia in contrast to $\operatorname{Htr}_{2 B}$ mRNA (Fig. 1A). Since commercially available 5-HT $2 \mathrm{~B}$ receptor antibodies are not specific for mouse receptor, we confirmed this tr $_{2 B}$ mRNA expression in vivo, by using $\mathrm{Cx} 3 \mathrm{Cr}^{\mathrm{GFP/+}}$ mice, in which microglial cells that express green fluorescent protein (GFP) ${ }^{29}$ are inserted by knock-in into the $C x 3 C r l$ gene. We then purified microglia (GFP+ cells) by fluorescence-activated cell sorting (FACS) on cell suspensions from cortex or brainstem at early stages of postnatal development: P3 and P9 (Fig. 1B-D-E). We first confirmed the purification of microglia by the expression of Mac1, a microglial marker, specifically in GFP+ fractions. RT-PCR analysis on these samples showed that freshly isolated microglia express $\mathrm{Htr}_{2 B}$ mRNA in the cortex and hippocampus (Fig. 1B,D) at P3 and P9 stages, and in the brainstem (Fig. 1E) at P9 stage. Htr $2 A$ mRNA was not detected in freshly isolated microglia, and $H_{2} r_{2}$ mRNA was visible only in fractions from P9 cortex and hippocampus. As $\operatorname{Htr}_{2 C} \mathrm{mRNA}$ is strongly expressed in brain, it might be a minor contaminant of the microglial fraction. Moreover, $H_{t r} r_{2 B}$ mRNA was undetectable in the GFPnegative fractions from cortex and hippocampus indicating a lack or a very low level of expression. In contrast, similar analyses showed that $\operatorname{Htr}_{2 B}$ mRNA from the brainstem is not only expressed in microglia but also in other GFP-negative cells (Fig. 1D), which is consistent with our previous results showing $\operatorname{Htr}_{2 B}$ expression in most of the serotonergic raphe neurons ${ }^{30}$. We also found $H_{t r} r_{2 B}$ expression in microglia freshly isolated from the thalamus of P9 $\mathrm{Htr}_{2 B}{ }^{+/+}$mice, a brain area we will subsequently examine (Fig. 1C). At the adult stage (8 weeks), we also observed its expression in microglia freshly isolated by FACS from the cortex, hippocampus, brainstem and thalamus (data not shown) in addition to other brain areas, which is consistent with a previous study that examined the cortex, cerebellum and striatum ${ }^{24}$.

Following the hypothesis that microglia and the serotonergic system could interact, we investigated whether they are spatially close to one another. As 5-HT can diffuse and is able to act a few micrometers (about ten) away from its source of release, a phenomenon known as "volume transmission" ${ }^{31}$, we looked for the presence of serotonergic axons around microglial cells using confocal imaging (Fig. 2A) and three-dimensional reconstruction (Fig. 2B, D and supplementary movie) of brain sections stained for the serotonin transporter SERT and the microglial marker Iba1 at P6. Serotonergic axons close to microglia could be observed everywhere in the brain and at various ages (data not shown). For the quantitative analysis, we focused on dLGN in the thalamus, in which axons from RGCs form synaptic connections with relay neurons in order to establish the retinogeniculate pathway of the visual system. We selected this region of interest because both microglia ${ }^{4,32}$ and 5-HT ${ }^{16}$ have been implicated in the refinement of these retinogeniculate projections during the two first postnatal weeks. The anatomical limits of this nucleus can be recognized with a staining of cell nuclei (see for example Fig. 3A). In the dLGN at P6, we observed that in a radius of $1 \mu \mathrm{m}$, there are tens (43 \pm 7 ) of varicosities around each microglia (Fig 2B-C); this number raises to $190 \pm 22$ using a radius of $5 \mu \mathrm{m}$ (Fig 2C).

We also observed in all reconstructed microglia some very close contacts between 5- 
HT varicosities and microglial processes (as illustrated in Fig 2D, which is an example taken from a P6 dLGN). These appositions could correspond to either local or transient closer interactions. To determine whether the proximity of SERT-positive axons and microglia require the presence of $5-\mathrm{HT}_{2 \mathrm{~B}}$ receptor, we analyzed the number of proximal varicosities around microglia of the dLGN of $\mathrm{Htr}_{2 B}{ }^{-{ }_{-}}$mice. Densities of serotonergic varicosities around the microglial surface were similar to those observed in $\mathrm{Htr}_{2 B}{ }^{+/+}$animals (Fig 2B-C), indicating that the presence of 5- $\mathrm{HT}_{2 \mathrm{~B}}$ receptor is not required for this structural organization. Taken together, these results show that microglia from postnatal mice express the $5-\mathrm{HT}_{2 \mathrm{~B}}$ receptor, the main microglial receptor for 5-HT, and might "sense" 5-HT originating notably from surrounding serotonergic fibers.

\section{Postnatal microglia invasion in the dLGN}

We next examined the distribution of microglia in fixed coronal sections of the developing brain, in $\mathrm{Cx} 3 \mathrm{Cr}^{\mathrm{GFP} /+}$ mice $^{29}$. As previously reported ${ }^{12}$, and in contrast to adult brain where microglia are homogenously distributed in parenchyma, the distribution of microglia in the early postnatal brain (P4) is heterogeneous (Fig. 3A). Again, we focused on the dLGN of the thalamus (Fig. 3A). At the age of P4, microglial cells are mainly located outside of dLGN, i.e. ventro lateral geniculate nucleus (VLGN) or ventro postero medial thalamus (VPM) and the surrounding tissue, with few microglia inside the dLGN (Fig. 3A). With age, the density of microglia inside the dLGN gradually increases: it almost doubles between P4 and P6 $\left(92.9 \pm 19.9\right.$ and $161.6 \pm 27.4$ microglia per $\mathrm{mm}^{2}$, respectively), to reach a 4-fold increase in adult animals (358.0 \pm 50.1 microglia per $\mathrm{mm}^{2}$ ) (Fig. 3B). In mice knocked-out for another GPCR, the CX3CR1 receptor for the chemokine fractalkine, the entry of microglia in the hippocampal structure is delayed, and this is correlated with a defective elimination of immature synapses. We next compared microglia invasion in the dLGN of $\mathrm{Htr}_{2 B}{ }^{-/-}$to $\mathrm{Htr}_{2 B}{ }^{+-}$ animals. However, the density (Fig 3C) of microglia inside the dLGN was similar in $\mathrm{Htr}_{2 B}{ }^{-1-}$ and $\mathrm{Htr}_{2 B}{ }^{+/-}$mice both at P5 and at P6, indicating that this receptor is not required for the process of microglia colonization in this structure. Although absolute number seems slightly higher in $\mathrm{Htr}_{2 B}{ }^{++}$(Fig 3B) compared to $\mathrm{Htr}_{2 B}{ }^{+/}$animals (Fig 3C) at P6, this difference was not significant and may be due to a slight difference in age, supporting the importance of using littermates. Nevertheless, 5-HT could mediate more subtle effects on the movement and orientation of microglial processes and for these reasons it was addressed in the subsequent experiments.

\section{Chemoattractant effect of 5-HT on microglial processes.}

As $5-\mathrm{HT}_{2 \mathrm{~B}}$ receptors are expressed in microglia, we focused on potential chemoattractant effects of 5-HT on microglia. Microglial cells are able to act by extending their processes toward, for example, synapses, and not only by moving their somas ${ }^{7,17,33,34}$. We investigated the effect of 5-HT on microglia in acute brain slices using two-photon microscopy. Fluorescent microglia of $\mathrm{Htr}_{2 B}^{+++} ; \mathrm{Cx}_{3} \mathrm{Cr}^{\mathrm{GFP} /+}$ mice were observed in the dLGN region on $300 \mu \mathrm{m}$ slices, at a depth over $50 \mu \mathrm{m}$. In line with the fact that axonal segregation in thalamic dLGN occurs during the first two postnatal weeks, we used P11-P14 mice (Fig. 4). We assessed the effect of a puff of 5-HT on the growth of neighboring microglial processes towards the source, and used ATP, a well-known chemoattractant for microglia ${ }^{24,35}$, as a positive control of microglia response. Indeed, some slight leak from the pipette tip could attract the most closest microglial processes even before the release of ATP, as seen in one of the supplementary movie. The chemoattractant effects were quantified by measuring the changes in mean velocity of the tip of the processes (Fig. 4B), as well as in length of proximal and distal processes with respect to the delivery site (Fig. 4C-D). A puff of 5-HT on dLGN slices triggered immediate increased motility of neighboring microglial processes showing 
increased velocity and extension of proximal processes towards the source, with roughly similar kinetics as ATP, whereas a release of saline solution did not trigger detectable effects (Fig. 4A-B-C, and Supplementary movies). These results indicate that, at least during the second postnatal week, thalamic microglia express functional 5-HT receptors that regulate the growth direction of their motile extensions. These data complement those from Krabbe et al. 24 , which showed that bath application of 5-HT increased the motility of microglial processes in a lesional context. Next, we repeated this experiment using P11-P14 slices from $\mathrm{Htr}_{2 B}{ }^{-/}$; $\mathrm{Cx} 3 \mathrm{Cr} 1^{\mathrm{GFP} /+}$ mice. In the dLGN of these mutant animals, no statistically significant microglial response to 5-HT could be observed, whereas ATP was efficient in microglia chemoattraction as in slices from $\mathrm{Htr}_{2 B}{ }^{+/+}$mice (Fig. 4B-C-D). In order to confirm the specific role of $5-\mathrm{HT}_{2 \mathrm{~B}}$ receptors in this process and to rule out a possible developmental effect of $\mathrm{Htr}_{2 B}{ }^{-/-}$mice, we performed 5-HT application on slices from $\mathrm{Htr}_{2 B}{ }^{+/+}$mice that had been preincubated with RS-127445, a selective antagonist of $5-\mathrm{HT}_{2 \mathrm{~B}}$ receptors ${ }^{36}$. This pretreatment completely prevented the response to 5-HT, confirming the specific involvement of $5-\mathrm{HT}_{2 \mathrm{~B}}$ receptors (Fig. 4D). Taken together, these results show that 5-HT is a chemoattractant to microglial processes via $5-\mathrm{HT}_{2 \mathrm{~B}}$ receptors.

We also investigated in a transwell assay the ability of microglia in culture to migrate through a membrane with $5-\mu \mathrm{m}$ pores. To investigate the potential effect of 5-HT, purified microglial cells were placed in the upper compartment in plain medium while 5-HT was in lower compartment in order to create a gradient. The staining of cell nuclei that crossed the membrane was quantified in order to assess the migration of microglial cell bodies. Such experimental setup could not reveal any significant chemotactic effect of 5-HT on microglia (Fig S1A), while ATP was efficient. No increase in mobility was detected when 5-HT was placed in both compartments, whereas ATP had, indeed, a chemokinetic effect (Fig S1B). It can be concluded that 5-HT was not able to modulate the mobility of microglia cell bodies in such experimental conditions. Assessment of the possible changes in phagocytic elimination of retinogeniculate projections in the thalamus of mutant mice is warranted for future experiments.

\section{$\mathrm{Htr}_{2 B}{ }^{-/-}$mice have defects in dLGN development.}

We then asked whether $\mathrm{Htr}_{2 B}{ }^{-/-}$mice could have defects in postnatal synaptic refinement / segregation of which is relying on both 5-HT and microglia. For this purpose, we looked at the segregation of ipsilateral and contralateral retinal projections onto the thalamic dLGN. This segregation was visualized via anterograde tracing of the retinal projections using the Cholera Toxin b subunit $(\mathrm{CTb})$ coupled to fluorochromes (each eye was injected with a different color $\mathrm{CTb}$ ) (Fig. 5A). A common way of analyzing the projection segregation in the dLGN is to measure the percentage of overlap between the ipsilateral and the contralateral regions ${ }^{37}$. Just after birth the two regions overlap and during the two postnatal weeks they segregate to eye specific areas of the thalamus. At P30, the synaptic refinement is mainly achieved and there is very little overlap between ipsi- and contralateral regions. We looked at the retinal projection segregation in the dLGN at P30, when segregation in the dLGN is accomplished, in $\mathrm{Htr}_{2 B}{ }^{-/-}$and $\mathrm{Htr}_{2 B}{ }^{+/+}$mice. Quantification of the eye-specific segregation did not reveal any significant difference at P30 in $\mathrm{Htr}_{2 B}{ }^{-/-}$and $\mathrm{Htr}_{2 B}{ }^{+/+}$mice, although a trend toward a reduced segregation was observed in $\mathrm{Htr}_{2 B}{ }^{-{ }_{-}}$mice (Fig. S2). However, we observed a phenotype in the dLGN of $\mathrm{Htr}_{2 B}{ }^{-/}$mice, which is especially well visible in the ipsilateral region. Indeed, the ipsilateral region of $\mathrm{Htr}_{2 B}{ }^{+/+}$mice was rather compact and well defined, whereas, it was more diffuse and patchy in $\mathrm{Htr}_{2 B}{ }^{-{ }_{-}}$mice (Fig. 5A). Such a compact pattern was observed in $70 \%$ of $\mathrm{Htr}_{2 B}{ }^{+/+}$but only in $23 \%$ of $\mathrm{Htr}_{2 B}{ }^{-\%}$ mice (Fig. 5B, p $<0.05$ ). In addition, the shape and the location of the ipsilateral projections were clearly more variable among $\mathrm{Htr}_{2 B}{ }^{-/-}$than $\mathrm{Htr}_{2 B}{ }^{+/+}$animals, as exemplified in Fig. 5C. In order to better visualize 
and quantify the heterogeneity observed in $\mathrm{Htr}_{2 B}{ }^{-/}$animals, ipsilateral regions of all of the animals of the same genotype were stacked to create a composite heat map for each genotype 38. Added together those images illustrate that the location of the ipsilateral region in the dLGN is much more variable within $\mathrm{Htr}_{2 B}{ }^{-/-}$animals. Whereas the heat map for $\mathrm{Htr}_{2 B}{ }^{+/+}$ genotype has a large and well organized hot area, which represents the overlap between all the stacked ipsilateral regions, the heat map of $\mathrm{Htr}_{2 B}{ }^{-/-}$mice is, in contrast, clearly disorganized and the hot area is smaller (Fig. 5D). A calculation of the number of overlapping pixels within the ipsilateral regions of all possible pairs of animals of a given genotype revealed that ipsilateral regions of $\operatorname{Htr}_{2 B}{ }^{+/+}$animals overlap with each other significantly more than those of $H_{t r}{ }_{2 B}^{-/-}$animals (Fig. 5D; $\mathrm{Htr}_{2 B}{ }^{+/+}$: mean overlap of $40.83 \pm 0.88 \%$ vs. $28.62 \pm 0.79 \%$ in $H t_{2 B}{ }^{-/-}$animals, $\left.\mathrm{p}<0.01\right)$. In contrast, contralateral regions are not different (Fig. $\mathbf{5 E}$ ). Altogether, these results show that $\mathrm{Htr}_{2 B}{ }^{-/-}$mice exhibit anatomical alterations restricted to ipsilateral retinal projections into the thalamus.

\section{Altered activation status of $\mathrm{Htr}_{2 B}{ }^{-/}$microglia.}

The irregular shape of the ipsilateral territory cannot be correlated, according to the preceding results, to a defect in microglia recruitment, while not excluding a role of local recruitment and activation of microglial processes by 5-HT. We first analyzed the microglial morphology by confocal microscopy on coronal slices of dLGN (thalamus) of P6 littermates. The soma size, number of processes and length of the longest microglia branch were defined for each visibly clear microglia. However, no statistical difference between genotypes could be observed (Fig 6A), excluding a strong contribution of the lack of 5- $\mathrm{HT}_{2 \mathrm{~B}}$ receptor to microglial structure. As 5-HT has been shown to regulate the functional polarization of human peripheral macrophages ${ }^{25}$, we then checked the activation state of microglia from $\operatorname{Htr}_{2 B}{ }^{-/-}$mice. The comparison of the expression level of a series of 84 immune markers was performed on microglial primary culture mRNA from $\mathrm{Htr}_{2 B}{ }^{-/-}$and $\mathrm{Htr}_{2 B}{ }^{+/+}$neonates. In particular, basal expression of inflammatory markers, including the chemokine receptors Ccr3, Ccr2, Ccr5, Cxcr5 and a member of the Tnf family, Tnfsf13, are upregulated in $\mathrm{Htr}_{2 B}{ }^{-1-}$ microglia (Fig 6B and S3). This result suggests that the lack of 5-HT $2 \mathrm{~B}$ receptors pushes the microglia toward a mild inflammatory state. Such results are consistent with the observation by de Las Casas-Engel et al., that the immune polarization of human macrophages is regulated by $5-\mathrm{HT}$, and notably through the $5-\mathrm{HT}_{2 \mathrm{~B}}$ receptor ${ }^{25}$. Thus, microglia from $\mathrm{Htr}_{2 B}{ }^{-1-}$ mice differ from $\mathrm{Htr}_{2 B}{ }^{+/+}$microglia in their activation state, which could affect their ability to mediate proper synaptic refinement.

\section{Conclusions}

For the last decade, it has been acknowledged that microglial cells are involved in promoting neuronal death and clearing apoptotic cells during brain development ${ }^{39}$. These immune cells are also essential for the proper wiring of neuronal networks, through the elimination of supernumerary synapses. Pruning of pre- and post-synaptic elements by microglia has been observed in the developing hippocampus where the neuron-to-microglia fractalkine signaling pathway can regulate synapse number and microglia recruitment ${ }^{3}$. This developmental elimination of inappropriate synapses also involves proteins of the classical complement cascade, a robust immune signaling pathway that tags debris or pathogens for phagocytosis 4 . Yet, other signaling pathways might influence microglia recruitment and function during cerebral development. In particular, 5-HT, a major actor of sensory map formation ${ }^{21}$, which has been also implicated in various psychiatric diseases ${ }^{40}$, and has been shown to modulate microglia phagocytosis ${ }^{24}$.

In this work, we report that, at early stages of postnatal brain development, microglia and the serotonergic system can interact. Microglial cells express $5-\mathrm{HT}_{2 \mathrm{~B}}$ receptors and are in 
close vicinity with serotonergic axons. During brain development, microglial $5-\mathrm{HT}_{2 \mathrm{~B}}$ receptors could thus be involved in many functions such as modulation of microglia extensions, chemoattraction and phagocytic capacities. Using focal 5-HT stimulation of microglia on acute postnatal brain slices, we found that 5-HT stimulation induced directional growth of microglial processes. Using slices from $\mathrm{Htr}_{2 B}{ }^{-/}$animals and pharmacological blockers, we confirmed that the 5-HT effect was mediated by $5-\mathrm{HT}_{2 \mathrm{~B}}$ receptors. Therefore, our results clearly show that $5-\mathrm{HT}$ via $5-\mathrm{HT}_{2 \mathrm{~B}}$ receptors can functionally modulate microglial process motility in postnatal dLGN.

In the healthy developing dLGN, the appropriate segregation of eye-specific projections requires microglial cells expressing CR3, which, after recognizing presynaptic elements tagged by complement proteins $\mathrm{C} 1 \mathrm{q}$ and $\mathrm{C} 3$, trigger their elimination ${ }^{4}$. Eye specific segregation of retinal projections in the thalamus depends also on appropriate 5-HT levels ${ }^{23}$. Indeed, eye-specific segregation fails to form in animals lacking monoamine oxidase $\mathrm{A}$ or SERT, i.e. when 5 -HT levels are increased ${ }^{16}$. This transient SERT expression by ipsilateral RGCs, from E14.5 to P9 ${ }^{22}$, can trigger a local 5-HT gradient. The lack of 5- $\mathrm{HT}_{2 \mathrm{~B}}$ receptors in microglia could thus abolish the ability of microglia to use this 5-HT gradient as a guide to locate where pruning is required. A defect in sensing this gradient by $5-\mathrm{HT}_{2 \mathrm{~B}}$ receptors could lead to abnormal activation or attraction of microglial processes, possibly inducing defects in synapse elimination in proper areas or unwanted elimination in ectopic areas (although not tested here). Furthermore, this may have functional consequences since a loss of ipsilateral drive has been associated with defects in binocular vision ${ }^{38}$.

By analyzing retinal projections in dLGN, we identified here, abnormal organization of retinal projections in $\mathrm{Htr}_{2 B}{ }^{-/-}$animals, which is consistent with this hypothesis. Additionally, 5-HT via 5- $\mathrm{HT}_{2 \mathrm{~B}}$ receptors appears necessary for the microglia to acquire proper developmental phenotype as revealed by basal expression of activation markers in $\mathrm{Htr}_{2 B}{ }^{-/}$microglia cultures. Our findings support the idea that 5-HT contributes to synaptic refinement during early postnatal development by implicating local recruitment of microglial processes and/or different microglial activation statuses. Thus, our data strongly support that the developmental phenotype observed in $\mathrm{Htr}_{2 B}{ }^{-/-}$animals is due to the lack of 5-HT activation of 5- $\mathrm{HT}_{2 \mathrm{~B}}$ receptors in postnatal microglial cells. 


\section{Methods.}

Wild-type $\mathrm{Htr}_{2 B}{ }^{+/+}$and $\mathrm{Htr}_{2 B}{ }^{-/-}$mice were on a $129 \mathrm{~S} 2 / \mathrm{SvPas}$ background as the embryonic stem cells used for homologous recombination. For two-photon experiments, double transgenic mice were generated by crossing these mice with $C \times 3 \mathrm{crl}^{\mathrm{GPP} /+}$ mice ${ }^{29}$. Four backcrosses were performed to reduce the contribution of C57/B16 genetic background from $C \times 3 c r 1^{\mathrm{GFP} /+}$ mice. All animals were bred at the animal facility of the Institut du Fer à Moulin. Young $(<\mathrm{P} 10)$ animals used for the quantification of microglial cells were littermates. All mice experiments were performed according to the EC directive 86/609/CEE, and have been approved by the local ethical committee $\left(\mathrm{N}^{\circ} 1170.01\right)$. After weaning, mice were housed together with a maximum of 5 mice per cage of the same genetic background until the beginning of the experimental protocol. In all the studies, the observer was blind to the experimental conditions being measured.

\section{Reagents.}

Solutions of serotonin-hydrochloride (SIGMA) were prepared extemporaneously in water. Aliquots of ATP stock solution in water and of RS-127445 (Tocris) in DMSO were stored at $20^{\circ} \mathrm{C}$.

\section{Inflammatory cytokines and receptors array.}

Quantitative mRNA expression analysis of 84 chemokines and their receptors was performed in primary microglia cultures with the mouse chemokine and receptor $\mathrm{RT}^{2}$ profiler PCR array (SABioscience, Qiagen). Total RNA was isolated from primary microglia cultures prepared from $\mathrm{Htr}_{2 B}{ }^{+/+}$or $\mathrm{Htr}_{2 B}{ }^{-/}$pups ( $\mathrm{n}=4$ cultures of each genotype) using the RNeasy mini kit protocol (Qiagen). Equal amounts (500ng) of RNA from each culture were then converted to cDNA using RT $^{2}$ first strand kit (SABioscience, Qiagen). PCRs were performed according to the manufacturer's protocol using $\mathrm{RT}^{2}$ profiler PCR array PAMM-011ZA (mouse inflammatory cytokines and receptors). The mRNA expression of each gene was normalized using the expression of the $\beta$-glucuronidase $(G u s b)$ as a housekeeping gene and compared with the data obtained with the control group $\left(\mathrm{Htr}_{2 B}{ }^{+/+}\right.$microglia cultures) according to the $2^{-}$ $\Delta \Delta \mathrm{CT}$ method ${ }^{41}$.

\section{Anterograde labeling of retinogeniculate projections in dLGN.} P30 mice were anesthetized with an intraperitoneal injections of ketamine-xylazine (ketamine $60 \mathrm{mg} / \mathrm{g}$ and xylazine $8 \mu \mathrm{g} / \mathrm{g}$, in $0.9 \%$ saline). $3 \mu \mathrm{l}$ of $0.2 \%$ cholera-toxin subunit B (CTb) conjugated to AlexaFluor 555 or 488 (Invitrogen/Molecular Probes) diluted in 1\% DMSO was injected into the eye intravitreally with a glass micropipette. After 2 days, mice were anesthetized with a sublethal dose of pentobarbital and perfused transcardially with $4 \%$ paraformaldehyde (PFA) as described in the "Brain slices preparation".

\section{Brain slices preparation.}

Mice were anesthetized with a sublethal dose of pentobarbital, perfused transcardially with $4 \%$ PFA in $0.1 \mathrm{M}$ phosphate buffer (PB), then their brains were collected and immersed in $4 \%$ PFA overnight, cryoprotected overnight in $30 \%$ sucrose in $\mathrm{PB}$, and sectioned coronally with a cryotome $(55$ or $100 \mu \mathrm{m})$. Eventually, the sections were processed for immunofluorescence or nuclei staining before being mounted in Mowiol 4-88 (Calbiochem) and imaged using a Leica DM 6000B fluorescent microscope.

\section{Immunofluorescence and confocal microscopy.}

Brain slices were washed one time in PB then incubated in permeabilizing and blocking 
solution $(0.25 \%$ gelatin and $0.1 \%$ triton in PB) for 30 min. Primary antibodies (Rabbit antiIba1, Wako, Japan, 1:600; Goat anti-SERT, Santa-Cruz, 1:1000) were diluted in PGT buffer $(0.125 \%$ gelatin and $0.1 \%$ triton in $\mathrm{PB})$. Samples were incubated for $48 \mathrm{~h}$ at $4{ }^{\circ} \mathrm{C}$ with gentle agitation. Secondary fluorochrome-conjugated antibodies (Donkey anti-Goat-Alexa647, Jackson Laboratories; Donkey anti-Rabbit Alexa488, Molecular Probes) were added in PGT buffer for $3.5 \mathrm{~h}$ at room temperature. After rinsing three times with PGT buffer and once with PB, sections were stained for nuclei with bis-benzimide (Sigma) for $15 \mathrm{~min}$, rinsed with PB and mounted in Mowiol. Samples were imaged using a Leica DM 6000B fluorescent microscope (form microglia invasion of the dLGN), a Leica SP5 (for microglia-serotonin interactions) or an Olympus Fluoview (for microglia morphology) confocal microscopes. Three-dimensional reconstructions were performed with Imaris software (Bitplane) based on stacks of confocal sections $(0.2 \mu \mathrm{m}$ apart $)$ acquired with a $63 \mathrm{x}$ objective. For comparative studies, all acquisition parameters were kept constant for the whole study. For the quantitative analysis of microglia-serotonergic fibers interactions, SERT-positive varicosities were considered as spots. We computed the number of spots at distances of 1 and $5 \mu \mathrm{m}$ from the surface of the cell.

Microglial morphology quantification was performed on 60x images obtained with FV10i (Olympus) confocal microscope. Images were acquired on coronal slices of dLGN (thalamus) of P6 littermates: $\operatorname{Htr}_{2 B}{ }^{-/-}(\mathrm{n}=3)$ and $\mathrm{Htr}_{2 B}{ }^{+/-}(\mathrm{n}=3)$. For each hemisphere, confocal images of 2-3 different regions were acquired. The soma size, number of processes and length of the longest microglia branch were defined for each clearly visible microglia (3 to 5 microglia per region). Statistical difference between genotypes was determined using Student's t-test.

\section{Analysis of distribution of ipsilateral fibers in the dLGN / Image analysis}

All image analyses were performed on 10x images obtained with a 10x/0.4 objective of Leica DM 6000B fluorescent microscope. Two images were acquired for each brain section containing the dLGN structure: one in a green and one in red channel (for ipsilateral and contralateral staining respectively). Animals where injection was incomplete, based on contralateral staining, were excluded from analysis. For each animal, a median reference section was chosen by a blind-to-the-genotype investigator, based on dLGN and vLGN shape of the contralateral staining. To prepare the heat maps, the images from the median sections of all the animals were aligned in the same orientation based on their contralateral staining. For each animal, the images (ipsi and contralateral staining) were then cropped into a smallest rectangle containing the entire dLGN visualized on the contralateral staining. The intrageniculate leaflet, the vLGN and the optic tract were excluded. Next, these reoriented and cropped images were resized to $400 \times 600$ pixels (width $\times$ height) and converted to binary images. All these were made using Image J software. Next the binary images of animals of the same genotype were stacked together and composite heat maps were created using Matlab (Mathworks), one for the ipsilateral and one for the contralateral staining. The color scale of each pixel corresponds to the number of animals which staining is present in this given location. In order to quantify the heat maps, a percent of overlap between each pair of images for each genotype was measured using Matlab (Mathworks). The average overlap between every two animals of the same genotype significance was evaluated by a two-sided permutation test. The qualification of compact versus diffuse ipsilateral region morphology was determined by a genotype-blind investigator, based on the shape of ipsilateral territories on three consecutive sections (the median and its previous and following sections). Statistical difference between genotypes was determined using Fischer's test. 


\section{Primary microglia culture and ex-vivo purification of fresh microglia}

For primary cultures of microglia, cortices from P1 pups $\left(\mathrm{Htr}_{2 B}{ }^{+/+}\right.$or $\left.\mathrm{Htr}_{2 B}{ }^{-/-}\right)$were dissociated by trituration after incubation with $0.25 \%$ trypsin. Cells were plated onto poly-ornithinecoated Petri dishes. Cells were grown in DMEM (Invitrogen, France) with pyruvate and low $(1 \mathrm{~g} / \mathrm{ml})$ glucose supplemented with $10 \%$ fetal bovine serum (BioWest, France). After 11 days in culture, microglia could be detached from the astrocytic layer by gentle shaking and processed for experimentation. For ex-vivo fresh purification, we used brain tissue from $\mathrm{C} \times 3 \mathrm{Crl}^{\mathrm{GFP} /+}$ animals (except for P9 thalamus samples) at P3 or P9 that had been anesthetized and perfused transcardially with PBS. Appropriate anatomical regions (cortex and hippocampus, or brain stem) were rapidly dissected on ice, chopped, digested with Trypsin for 15 minutes at $37^{\circ} \mathrm{C}$, rinsed, treated for 5 minutes with DNAse, rinsed, mechanically dissociated using a fire-polished Pasteur glass pipet, and filtered on a $70 \mu \mathrm{m}$ mesh prior to cell sorting on a FACSAria I (Becton Dickinson). DAPI (Life Technologies) was added to the cell suspensions just before cell sorting in order to gate only living cells. GFP-positive fractions were $97-99 \%$ pure. Microglia from P9 thalamus of $\mathrm{Htr}_{2 B}{ }^{+/+}$mice were purified as described in Krabbe et al. ${ }^{24}$ using a $25-75 \%$ Percoll gradient. Microglia collected at the $25-75 \%$ interface were $>90 \%$ pure as checked by FACS (MACSQuant Miltenyi) using a staining with an antiCD11b coupled to FITC (Miltenyi Biotec).

\section{Two photon microscopy}

Brain slices were prepared from mice aged from P11 to P14, as previously described ${ }^{42}$. Briefly, mice were decapitated, their brain removed, and coronal brain slices $(300 \mu \mathrm{m}$ thickness) were obtained with a HM650 microtome (Microm, France). Slices were prepared in an ice-cold solution of the following composition (in $\mathrm{mM}$ ): choline $\mathrm{Cl} \mathrm{110}$; glucose 25; $\mathrm{NaHCO}_{3} 25 ; \mathrm{MgCl}_{2} 7$; ascorbic acid 11.6; $\mathrm{Na}^{+}$-pyruvate $3.1 ; \mathrm{KCl} 2.5 ; \mathrm{NaH}_{2} \mathrm{PO}_{4} 1.25$; and $\mathrm{CaCl}_{2} 0.5$ saturated with $5 \% \mathrm{CO}_{2} / 95 \% \mathrm{O}_{2}$. Coronal slices $(250 \mu \mathrm{m})$ were stored at room temperature in $95 \% \mathrm{O}_{2} / 5 \% \mathrm{CO}_{2}$-equilibrated artificial cerebrospinal fluid (ACSF) containing the following (in $\mathrm{mM}$ ): $\mathrm{NaCl} 124 ; \mathrm{NaHCO}_{3} 26.2 ;$ glucose $11 ; \mathrm{KCl} 2.5 ; \mathrm{CaCl}_{2} 2.5 ; \mathrm{MgCl}_{2} 1.3$; and $\mathrm{NaH}_{2} \mathrm{PO}_{4}$ 1. During 2-photon imaging, brain slices were continuously perfused with this solution saturated with $5 \% \mathrm{CO}_{2} / 95 \% \mathrm{O}_{2}$, at a rate of $2 \mathrm{ml} / \mathrm{min}$, in a recording chamber of $\sim 1$ $\mathrm{ml}$ volume maintained at $32^{\circ} \mathrm{C}$. A pipette containing ACSF, 5-HT $(5 \mu \mathrm{M})$, 5-HT $(5 \mu \mathrm{M})$ with RS-127445 $(5 \mu \mathrm{M})$, or ATP $(500 \mu \mathrm{M})$ was placed in the center of the dLGN. After 10 minutes of baseline recording, a gentle positive pressure was applied to the pipette for local application. For experiments with RS-127445, the antagonist was bath applied at $5 \mu \mathrm{M}$ and slices were preincubated for 10 minutes prior to local application of 5-HT. Movement of microglia processes was followed by recording a fluorescent image every minute with a 2photon MP5 upright microscope (Leica Microsystems, Germany) with a 250.95 NA waterimmersion objective and a Chameleon Ultra2 Ti:sapphire laser (Coherent, Germany) tuned to $920 \mathrm{~nm}$ for GFP excitation. Resonant scanners (8 Khz) were used for Z-stack image acquisition. A two-photon emission filter was used to reject residual excitation light (SP 680, Chroma Technology). A fluorescence cube containing a 525/50 emission filter and a 560 dichroic filter was used for collecting fluorescence signals.

Movies were obtained by projecting a stack of images aquired at least at $50 \mu \mathrm{m}$ from the slice surface to avoid microglia activated by the sectionning. Only slices with obvious scanning movements of microglial processes in basal conditions were used for treatment and subsequent analysis. All the microglia in field recorded were analyzed, which allowed inclusion of microglial processes in a radius of $100 \mu \mathrm{m}$ from the pipet tip. The velocity of the microglia process was extracted from 2-photons images with the "Manual Tracking" plugin of image J. For each slices, on or two process of the microglia, located in a radius of $100 \mu \mathrm{m}$ from the pipette, were followed during 30 minutes after the puff. 


\section{Statistical analysis}

To determine differences between the experimental groups, parameters were analyzed by either an unpaired Student's t-test or one- or two-way analysis of variance (ANOVA) with genotypes and treatments as main factors depending on the experimental design. Bonferroni's test was used for post hoc comparisons. In all cases, $\mathrm{p}<0.05$ was considered statistically significant. 


\section{Supporting Information Available:}

Supplementary data include methods and results for ATP and 5-HT effects on microglia by a transwell assay, for the comparison between ipsilateral projections in dLGN of $\mathrm{Htr}_{2 B}{ }^{-/-}$vs. $\mathrm{Htr}_{2 B}{ }^{+/+}$mice, and Volcano plot for mouse chemokines and receptors of $\mathrm{Htr}_{2 B}{ }^{-/-}$vs. Htr ${ }_{2 B}{ }^{+/+}$ mice. Supplementary movies display the effects of serotonin application on the growth of neighboring microglia processes. This material is available free of charge via the Internet at http://pubs.acs.org.

Abbreviations. embryonic day (E); postnatal day (P) retinal ganglion cells (RGCs); dorsal lateral geniculate nucleus (dLGN) serotonin (5-Hydroxytryptamine, 5-HT); monoamine oxidase A (MAOA) serotonin transporter (SERT); green fluorescent protein (GFP); fluorescence-activated cell sorting (FACS); cholera Toxin b subunit (CTb); complement receptor 3 (CR3); paraformaldehyde (PFA); phosphate buffer (PB); artificial cerebrospinal fluid (ACSF); analysis of variance (ANOVA).

\section{Author Information.}

Co-corresponding authors :

Luc Maroteaux, Email : luc.maroteaux@upmc.fr; Tel: (33) 0145876123

Anne Roumier Email : anne.roumier@inserm.fr Tel: (33) 0145876124

Institut du Fer à Moulin UMR-S839 INSERM/UPMC 17 rue du Fer à Moulin 75005 Paris

Fax : (33) 0145876132

\section{Author Contribution.}

Marta Kolodziejczak, performed all the dLGN studies and transwell assays

Catherine Béchade, performed the PCR arrays and microglia purification

Nicolas Gervasi, performed two-photons imaging studies

Theano Irinopoulou, made the Imaris reconstructions and analysis of microglia-serotonin interactions

Sophie M. Banas, performed mice breeding and helped with microglia purification

Corinne Cordier, performed the microglia sorting by FACS

Alexandra Rebsam, helped with dLGN experiments and interpretation

Anne Roumier performed the studies on serotonin receptor expression, confocal imaging, experimental design, writing and funding

Luc Maroteaux supervised the analysis, experimental design, writing and funding

\section{Acknowledgment.}

We thank Florence Niedergang (Cochin Institute) for the cell biology advice, Ivana D'Andrea for help with quantifications, Melissa Martin for English editing, and Mythili Savariradjane from the Imaging facility of the IFM. 


\section{Funding Sources}

This work has been supported by funds from the Centre National de la Recherche Scientifique, the Institut National de la Santé et de la Recherche Médicale, the Université Pierre et Marie Curie, and by grants from the Fondation de France, the Fondation pour la Recherche Médicale "Equipe FRM DEQ2014039529", the French Ministry of Research (Agence Nationale pour la Recherche ANR-12-BSV1-0015-01 and the Investissements d'Avenir programme ANR-11-IDEX-0004-02). LM's team is part of the École des Neurosciences de Paris Ile-de-France network and of the Bio-Psy Labex and as such this work was supported by French state funds managed by the ANR within the Investissements d'Avenir programme under reference ANR-11-IDEX-0004-02. MK has been supported by fellowships from the Université Pierre et Marie Curie (Emergence-UPMC program) and the Bio-Psy Labex. AR was awarded an Emergence-UPMC grant (EME 1121) including the PhD fellowship to MK by the Université Pierre et Marie Curie.

\section{Conflict of Interest}

The authors declare no conflict of interest. 


\section{FIGURE LEGENDS}

Figure 1: Specific microglial expression of $\boldsymbol{H t r}_{2 B}$ in primary culture and in the developing brain. (A) RT-PCR experiments on primary culture of microglia (top) and whole hippocampus at P0 (middle) and P30 (bottom) show that tr $_{2 B}$ is the main 5-HT receptor gene expressed in cultured microglia whereas a large diversity of 5-HT receptors subtypes is expressed in whole tissue. Cyp: Cyclophilin-B (reference gene); 1A, 1B, etc: Htr ${ }_{1 A}, H_{t r} r_{1 B}$, etc. The bands in lanes $1 \mathrm{~A}$ and $1 \mathrm{~F}$ of the top gel, not having the proper size, are non-specific. (B, D) RT-PCR on microglial and non-microglial cells purified by FACS from cortex and hippocampus of $C x 3 c r 1^{G F P /+}$ mice at P3 (B) or P9 (D). At each age, cells were sorted into a GFP positive (GFP+) and a GFP negative (GFP-) fractions. RT-PCR against the specific microglial gene $\mathrm{Macl}$ confirmed that the GFP+ fraction, but not the GFP- fraction, contained microglia. GluN1: NR1 subunit of the NMDAR. (C) RT-PCR on microglia cells purified on Percoll gradient from thalamus at P9, showing a signal for $H_{t r}$. (E) RT-PCR on cells sorted from brain stem of $\mathrm{Cx}_{3} \mathrm{crl}^{G F P /+}$ mice at P9, showing a signal for $\mathrm{Htr}_{2 B}$ in both GFP+ and GFP- fractions.

Figure 2: Proximity of microglial processes and serotonergic varicosities in vivo. (A) Projection of a $14.4 \mu \mathrm{m}$-thick stack of confocal images from the dLGN of a P6 mouse, showing numerous sites of apposition (asterisks) between microglia stained with anti-Iba1 antibody (green), and serotonergic axons stained with anti-serotonin transporter antibody (SERT-red). Note the typical presence of varicosities all along the serotonergic axons. Scale bar: $10 \mu \mathrm{m}$. (B) Three-dimensional reconstruction from confocal images, showing the serotonergic varicosities located at less than $1 \mu \mathrm{m}$ from the microglial surface. Due to their unique morphology, the serotonergic axons could be fragmented and represented by dots (purple) corresponding to individual varicosities. Scale bar: $10 \mu \mathrm{m}$. (C) Number of serotonergic varicosities situated at less than 1 or $5 \mu \mathrm{m}$ from a microglia, in the dLGN of P10 $\mathrm{Htr}_{2 B}{ }^{+/+}$and $\mathrm{Htr}_{2 B}{ }^{-/-}$animals $\left(9\right.$ microglia were reconstructed from $2 \mathrm{Htr}_{2 B}{ }^{+/+}$mice and 7 from $2 \mathrm{Htr}_{2 B}{ }^{-/}$mice). No difference was observed among genotypes. (D). Typical threedimensional reconstruction from a confocal image, showing very close contacts between microglial processes and serotonergic axons. Scale bar: $7 \mu \mathrm{m}$. Left: overview, right: detail showing the alignment of at least five varicosities along a microglial (stars). Scale bar: $2 \mu \mathrm{m}$. See supplementary movie of this reconstruction.

Figure 3: Colonization of the dLGN by microglia during postnatal development.

(A) Distribution of microglia mice visualized in $\mathrm{Cx} 3 \mathrm{crl}^{\mathrm{GFP} / \mathrm{+}}$ mice ${ }^{29}$ in cortex and thalamus at P4. Scale bar: $500 \mu \mathrm{m}$; upper left inset: nuclei staining with Bis-Benzimide; white square: area magnified on the right panels, including the dLGN. There is a progressive increase in the density of microglia in the dLGN between P4 and P30. The dLGN limits are shown by white dotted line deduced from the nuclear staining with Bis-Benzimide. Top: microglia (GFP), bottom: nuclei (Bis-Benzimide). Scale bars: $250 \mu \mathrm{m}$. (B) Density of microglia counted in the dLGN at P4, P6 and P30 of ttr $_{2 B}{ }^{+/+}$mice. P4 (92.9 19.9 microglia per $\mathrm{mm}^{2}, \mathrm{n}=8$ slices from 4 animals), P6 (161.6 \pm 27.4 microglia per $\mathrm{mm}^{2}, \mathrm{n}=7$ slices from 3 animals) and P30 $\left(358 \pm 50\right.$ microglia per $\mathrm{mm}^{2}, \mathrm{n}=3$ slices from 2 animals) (Mean $\left.\pm \mathrm{SD}\right)$. One-way ANOVA, F $(2,16)=154.8 \mathrm{P}<0.0001$, followed by Bonferroni multiple comparison test $(* * *: \mathrm{p}<0.001$ and $* * * *: p<0.0001)$. (C) Density of Iba1-stained microglia was counted in the dLGN at P5 $\left(\right.$ Htr $_{2 B}{ }^{+/} 70.75 \pm 24.46$ microglia per $\mathrm{mm}^{2}, \mathrm{n}=4 ;$ Htr $_{2 B}{ }^{-/} 67.84 \pm 12.23$ microglia per $\mathrm{mm}^{2}, \mathrm{n}=$ 5)- P6 $\left(\right.$ Htr $_{2 B}{ }^{+/} 121.00 \pm 17.94$ microglia per $\mathrm{mm}^{2}, \mathrm{n}=6 ; \mathrm{Htr}_{2 B}{ }^{-/-} 127.50 \pm 15.62$ microglia per $\left.\mathrm{mm}^{2}, \mathrm{n}=4\right)($ Mean $\pm \mathrm{SD})$; animals used for quantification were littermates; ns, non significant by one-way ANOVA. 
Figure 4: 5-HT $2 \mathrm{~B}$ receptors-mediated chemoattraction of microglial processes toward 5HT in dLGN. (A) Maximal projections of stacks of 2-photon images taken 5 min before and $15 \mathrm{~min}$ and $30 \mathrm{~min}$ after a local application (red dot in the center of the "t=-5 min" image) of artificial cerebrospinal fluid (ACSF), 5-HT (5 $\mu \mathrm{M}), 5-\mathrm{HT}(5 \mu \mathrm{M})$ plus RS-127445 (RS, $5 \mu \mathrm{M})$ or ATP $(500 \mu \mathrm{M})$ on acute slices of $\mathrm{Htr}_{2 B}{ }^{+/+}$(left) or $\mathrm{Htr}_{2 B}{ }^{-/-}$(right); $\mathrm{Cx} 3 \mathrm{crl}{ }^{\mathrm{GFP} /+}$ mice. All recordings were done in the dLGN of P11-P14 mice. ATP was used as positive control of microglial response. Scale bars: $50 \mu \mathrm{m}$. (B) The average velocity of the processes was calculated using the plugin "Manual Tracking" of Image J. The comparison of process velocity was done by one way ANOVA and Bonferroni post-hoc test $(* * * *: p<0.0001$; ns: p>0.05; for ACSF: $\mathrm{n}=4$ slices from $3 \mathrm{Htr}_{2 B}{ }^{+/+}$and 3 slices from $3 \mathrm{Htr}_{2 B}{ }^{-/-}$animals; for ATP: $\mathrm{n}=7$ slices from $5 \mathrm{Htr}_{2 B}{ }^{+/+}$and 7 slices from $4 \mathrm{Htr}_{2 B}{ }^{-/-}$animals; for 5-HT: $\mathrm{n}=7$ slices from 4 animals, both for $\mathrm{Htr}_{2 B}{ }^{+/+}$and $\mathrm{Htr}_{2 B}{ }^{-/-}$genotypes). (C) The kinetic of processes extension was quantified on the recordings for ATP on $\mathrm{Htr}_{2 B}{ }^{+/+}$and $\mathrm{Htr}_{2 B}{ }^{-/-}$and for 5-HT on $\mathrm{Htr}_{2 B}{ }^{+/+}$mice. No difference in extension kinetics could be detected for ATP or 5-HT. (D) For each slice, processes distal and proximal to the tip of the pipette delivering the ACSF, 5-HT, or ATP solutions, were analyzed to show the chemoattractant effect. The quantification was done by comparing the length of microglial processes before and after the stimulation. The comparison of proximal vs. distal length was done by one way ANOVA and Bonferroni posthoc test $(* * * *: p<0.0001$; ns: pairs of proximal/distal dendrites where $\mathrm{p}>0.05$; for $\mathrm{ACSF}: \mathrm{n}=4$ slices from $3 \mathrm{Htr}_{2 B}{ }^{+/+}$and 3 slices from $3 \mathrm{Htr}_{2 B}{ }^{-/-}$animals; for ATP: $\mathrm{n}=7$ slices from $5 \mathrm{Htr}_{2 B}{ }^{+/+}$ and 7 slices from $4 \mathrm{Htr}_{2 B}{ }^{-/-}$animals; for 5-HT condition: $\mathrm{n}=7$ slices from 4 animals, both for $\mathrm{Htr}_{2 B}{ }^{+/+}$and $\mathrm{Htr}_{2 B}{ }^{-/-}$genotypes; for 5 -HT+RS: $\mathrm{n}=3$ slices from $2 \mathrm{Htr}_{2 B}{ }^{+/+}$animals). See supplementary movies for 5-HT or ATP on $\mathrm{Htr}_{2 B}{ }^{+/+}$or $\mathrm{Htr}_{2 B}{ }^{-/-}$slices.

Figure 5: Defects in ipsilateral projections organization in $\mathbf{H t r}_{2 B}{ }^{-/-}$mice. (A) Dye-labeled retinogeniculate projections in dLGN of $\mathrm{Htr}_{2 B}{ }^{+/+}$and $\mathrm{Htr}_{2 B}{ }^{-/-}$mice. Projections from retinal ganglion cells from the ipsilateral retina are in green and those from the contralateral retina are in red. In both $\mathrm{Htr}_{2 B}{ }^{+/+}$and $\mathrm{Htr}_{2 B}{ }^{-/-}$animals, projections from ipsilateral and contralateral retinas are segregated, however, the region occupied by ipsilateral projections in the $\mathrm{Htr}_{2 B}{ }^{+/+}$ animal is compact and has a regular triangle-like shape, whereas it is diffuse and patchy in the $\mathrm{Htr}_{2 B}{ }^{-/}$animal. Scale bars: $100 \mu \mathrm{m}$. (B) The majority of $\mathrm{Htr}_{2 B}{ }^{+/+}$mice have a compact ipsilateral region, whereas majority of $\mathrm{Htr}_{2 B}{ }^{-/-}$mice have a diffuse ipsilateral region $(\mathrm{n}=10$ 13, $\mathrm{p}<0.05$ Fischer's test). (C) In each column, pictures from three animals of a given genotype illustrate the interindividual stability versus heterogeneity in the shape of the region occupied by ipsilateratal projections in $\mathrm{Htr}_{2 B}{ }^{+/+}$(left) versus $\mathrm{Htr}_{2 B}{ }^{-/-}$(right) mice, respectively. Scale bars: $100 \mu \mathrm{m}$. Heatmaps have been created by superposition of binary images of ipsilateral (D) and contralateral (E) regions from $\mathrm{Htr}_{2 B}{ }^{+/+}$or $\mathrm{Htr}_{2 B}{ }^{-/-}$mice. The color scale corresponds to the number of animals, in which projections are present in a given location (pixel). The surfaces with "hot" colors, which represent the regions of most overlap between mice, are considerably reduced for the ipsilateral region, but not for the contralateral region of $\mathrm{Htr}_{2 B}{ }^{-/-}$compared to $\mathrm{Htr}_{2 B}{ }^{+/+}$animals, indicating a defect in the precision of the location of the ipsilateral projections in these mice $(n=12$ animals per genotype). On the right, the robustness of the location of the ipsilateral and contralateral projections among individuals was quantified by calculating the percent overlap between every two animals of the same genotype. Ipsilateral overlap is significantly reduced in $\mathrm{Htr}_{2 B}{ }^{-/-}$mice compared to $\mathrm{Htr}_{2 B}{ }^{+/+}$ mice (Two-sided permutation test, $\mathrm{p}<0.01$ ), while the contralateral overlap is not significantly different. 
Figure 6: Characterization of $\boldsymbol{H t r}_{2 B}{ }^{-/-}$microglia. A) Morphology of microglia of the dLGN from $\mathrm{Htr}_{2 B}{ }^{-/+}$or $\mathrm{Htr}_{2 B}{ }^{-/-}$littermates at P6. Representative stacks of confocal images $(40 \mu \mathrm{m})$ (top) that were used to assess the soma diameter (mean Feret diameter), the number of primary processes and the length of the longest process (anti-Ibal staining) per microglia of dLGN in sections from $\mathrm{Htr}_{2 B}{ }^{-/+}$or $\mathrm{Htr}_{2 B}{ }^{-/}$littermates at P6 (bottom). This analysis revealed no difference; $\mathrm{n}=3$ mice per genotype, with 3 to 5 microglia from at least 3 different locations within dLGN. B) Overexpression of inflammatory markers in $\mathrm{Htr}_{2 B}{ }^{-/-}$microglia by comparison to $\mathrm{Htr}_{2 B}{ }^{+/+}$microglia. cDNAs prepared from primary microglia cultures of $\mathrm{Htr}_{2 B}{ }^{+/+}$or $\mathrm{Htr}_{2 B}{ }^{-/-}$ pups were subjected to $\mathrm{RT}^{2}$ profiler PCR array PAMM-011ZA (mouse inflammatory cytokines and receptors) as described in Materials and Methods. The levels of transcripts in the $\operatorname{Htr}_{2 B}{ }^{-/-}$microglial cultures are expressed relative to the levels in the $\mathrm{Htr}_{2 B}{ }^{+/+}$microglial cultures. Significant differences between $\mathrm{Htr}_{2 B}{ }^{+/+}$or $\mathrm{Htr}_{2 B}{ }^{-/-}$microglia cultures were determined using the Student's $t$ test. ( $\mathrm{n}=4$ cultures of each genotype; ${ }^{*} \mathrm{p}<0.05 ;{ }^{* * *} \mathrm{p}<0.001$ ).

\section{Graphic for the Table of Contents}




\section{References.}

(1) Pont-Lezica, L.; Bechade, C.; Belarif-Cantaut, Y.; Pascual, O.; Bessis, A., (2011) Physiological roles of microglia during development. J Neurochem 119 (5), 901-8.

(2) Squarzoni, P.; Oller, G.; Hoeffel, G.; Pont-Lezica, L.; Rostaing, P.; Low, D.; Bessis, A.; Ginhoux, F.; Garel, S., (2014) Microglia modulate wiring of the embryonic forebrain. Cell Rep 8 (5), 1271-9.

(3) Paolicelli, R. C.; Bolasco, G.; Pagani, F.; Maggi, L.; Scianni, M.; Panzanelli, P.; Giustetto, M.; Ferreira, T. A.; Guiducci, E.; Dumas, L.; Ragozzino, D.; Gross, C. T., (2011) Synaptic pruning by microglia is necessary for normal brain development. Science 333 (6048), 1456-8.

(4) Schafer, D. P.; Lehrman, E. K.; Kautzman, A. G.; Koyama, R.; Mardinly, A. R.; Yamasaki, R.; Ransohoff, R. M.; Greenberg, M. E.; Barres, B. A.; Stevens, B., (2012) Microglia sculpt postnatal neural circuits in an activity and complement-dependent manner. Neuron 74 (4), 691-705.

(5) Kettenmann, H.; Kirchhoff, F.; Verkhratsky, A., (2013) Microglia: new roles for the synaptic stripper. Neuron 77 (1), 10-8.

(6) Parkhurst, C N.; Yang, G.; Ninan, I.; Savas, J N.; Iii, J R. Y.; Lafaille, J J.; Hempstead, B L.; Littman, D R.; Gan, W.-B., (2013) Microglia Promote Learning-Dependent Synapse Formation through Brain-Derived Neurotrophic Factor. Cell 155 (7), 15961609.

(7) Li, Y.; Du, X.-F.; Liu, C.-S.; Wen, Z.-L.; Du, J.-L., (2012) Reciprocal regulation between resting microglial dynamics and neuronal activity in vivo. Dev Cell 23 (6), 1189-202.

(8) Wake, H.; Moorhouse, A. J.; Miyamoto, A.; Nabekura, J., (2012) Microglia: actively surveying and shaping neuronal circuit structure and function. Trends Neurosci 36 (4), 209-17.

(9) Ginhoux, F.; Greter, M.; Leboeuf, M.; Nandi, S.; See, P.; Gokhan, S.; Mehler, M. F.; Conway, S. J.; Ng, L. G.; Stanley, E. R.; Samokhvalov, I. M.; Merad, M., (2010) Fate mapping analysis reveals that adult microglia derive from primitive macrophages. Science 330 (6005), 841-5.

(10) Swinnen, N.; Smolders, S.; Avila, A.; Notelaers, K.; Paesen, R.; Ameloot, M.; Brone, B.; Legendre, P.; Rigo, J. M., (2013) Complex invasion pattern of the cerebral cortex bymicroglial cells during development of the mouse embryo. Glia 61 (2), 150-63.

(11) Hanisch, U.-K.; Kettenmann, H., (2007) Microglia: active sensor and versatile effector cells in the normal and pathologic brain. Nat Neurosci 10 (11), 1387-94.

(12) Arnoux, I.; Hoshiko, M.; Mandavy, L.; Avignone, E.; Yamamoto, N.; Audinat, E., (2013) Adaptive phenotype of microglial cells during the normal postnatal development of the somatosensory "Barrel" cortex. Glia 61 (10), 1582-94.

(13) Huberman, A. D.; Feller, M. B.; Chapman, B., (2008) Mechanisms underlying development of visual maps and receptive fields. Annu Rev Neurosci 31, 479-509.

(14) Assali, A.; Gaspar, P.; Rebsam, A., (2014) Activity dependent mechanisms of visual map formation--from retinal waves to molecular regulators. Semin Cell Dev Biol 35, $136-46$.

(15) Godement, P.; Salaun, J.; Imbert, M., (1984) Prenatal and postnatal development of retinogeniculate and retinocollicular projections in the mouse. J Comp Neurol 230 (4), $552-75$.

(16) Upton, A. L.; Salichon, N.; Lebrand, C.; Ravary, A.; Blakely, R.; Seif, I.; Gaspar, P., (1999) Excess of serotonin (5-HT) alters the segregation of ispilateral and contralateral retinal projections in monoamine oxidase A knock-out mice: possible role of 5-HT 
uptake in retinal ganglion cells during development. J Neurosci 19 (16), 7007-24.

(17) Wake, H.; Moorhouse, A. J.; Jinno, S.; Kohsaka, S.; Nabekura, J., (2009) Resting microglia directly monitor the functional state of synapses in vivo and determine the fate of ischemic terminals. J Neurosci 29 (13), 3974-80.

(18) Tremblay, M. E.; Lowery, R. L.; Majewska, A. K., (2010) Microglial interactions with synapses are modulated by visual experience. PLoS Biol 8 (11), e1000527.

(19) Hoshiko, M.; Arnoux, I.; Avignone, E.; Yamamoto, N.; Audinat, E., (2012) Deficiency of the microglial receptor CX3CR1 impairs postnatal functional development of thalamocortical synapses in the barrel cortex. J Neurosci 32 (43), 15106-11.

(20) Stevens, B.; Allen, N. J.; Vazquez, L. E.; Howell, G. R.; Christopherson, K. S.; Nouri, N.; Micheva, K. D.; Mehalow, A. K.; Huberman, A. D.; Stafford, B.; Sher, A.; Litke, A. M.; Lambris, J. D.; Smith, S. J.; John, S. W. M.; Barres, B. A., (2007) The classical complement cascade mediates CNS synapse elimination. Cell 131 (6), 1164-78.

(21) Gaspar, P.; Cases, O.; Maroteaux, L., (2003) The developmental role of serotonin: news from mouse molecular genetics. Nat Rev Neurosci 4 (12), 1002-12.

(22) García-Frigola, C.; Herrera, E., (2010) Zic2 regulates the expression of Sert to modulate eye-specific refinement at the visual targets. EMBO J 29 (18), 3170-83.

(23) Upton, A. L.; Ravary, A.; Salichon, N.; Moessner, R.; Lesch, K. P.; Hen, R.; Seif, I.; Gaspar, P., (2002) Lack of 5-HT(1B) receptor and of serotonin transporter have different effects on the segregation of retinal axons in the lateral geniculate nucleus compared to the superior colliculus. Neuroscience 111 (3), 597-610.

(24) Krabbe, G.; Matyash, V.; Pannasch, U.; Mamer, L.; Boddeke, H. W. G. M.; Kettenmann, H., (2012) Activation of serotonin receptors promotes microglial injuryinduced motility but attenuates phagocytic activity. Brain Behav Immun 26 (3), 419-28.

(25) de Las Casas-Engel, M.; Domínguez-Soto, A.; Sierra-Filardi, E.; Bragado, R.; Nieto, C.; Puig-Kroger, A.; Samaniego, R.; Loza, M.; Corcuera, M. T.; Gómez-Aguado, F.; Bustos, M.; Sánchez-Mateos, P.; Corbí, A. L., (2013) Serotonin skews human macrophage polarization through HTR2B and HTR7. J Immunol 190 (5), 2301-10.

(26) Bevilacqua, L.; Doly, S.; Kaprio, J.; Yuan, Q.; Tikkanen, R.; Paunio, T.; Zhou, Z.; Wedenoja, J.; Maroteaux, L.; Diaz, S.; Belmer, A.; Hodgkinson, C.; Dell'Osso, L.; Suvisaari, J.; Coccaro, E.; Rose, R.; Peltonen, L.; Virkkunen, M.; Goldman, D., (2010) A population-specific HTR2B stop codon predisposes to severe impulsivity. Nature 468 (8), 1061-1066.

(27) Glebov, K.; Löchner, M.; Jabs, R.; Lau, T.; Merkel, O.; Schloss, P.; Steinhäuser, C.; Walter, J., (2014) Serotonin stimulates secretion of exosomes from microglia cells. Glia.

(28) Launay, J.-M.; Hervé, P.; Callebert, J.; Mallat, Z.; Collet, C.; Doly, S.; Belmer, A.; Diaz, S. L.; Hatia, S.; Côté, F.; Humbert, M.; Maroteaux, L., (2012) Serotonin 5-HT2B receptors are required for bone-marrow contribution to pulmonary arterial hypertension. Blood 119 (7), 1772-1780.

(29) Jung, S.; Aliberti, J.; Graemmel, P.; Sunshine, M. J.; Kreutzberg, G. W.; Sher, A.; Littman, D. R., (2000) Analysis of fractalkine receptor CX(3)CR1 function by targeted deletion and green fluorescent protein reporter gene insertion. Mol Cell Biol 20 (11), 4106-14.

(30) Diaz, S. L.; Doly, S.; Narboux-Nême, N.; Fernandez, S.; Mazot, P.; Banas, S.; Boutourlinsky, K.; Moutkine, I.; Belmer, A.; Roumier, A.; Maroteaux, L., (2012) 5HT2B receptors are required for serotonin-selective antidepressant actions. Mol Psychiatry 17, 154-163.

(31) Zoli, M.; Jansson, A.; Syková, E.; Agnati, L. F.; Fuxe, K., (1999) Volume transmission in the CNS and its relevance for neuropsychopharmacology. Trends Pharmacol Sci 20 
(4), 142-50.

(32) Bialas, A. R.; Stevens, B., (2013) TGF- $\beta$ signaling regulates neuronal C1q expression and developmental synaptic refinement. Nat Neurosci 16 (12), 1773-82.

(33) Nimmerjahn, A.; Kirchhoff, F.; Helmchen, F., (2005) Resting microglial cells are highly dynamic surveillants of brain parenchyma in vivo. Science 308 (5726), 1314-8.

(34) Davalos, D.; Grutzendler, J.; Yang, G.; Kim, J. V.; Zuo, Y.; Jung, S.; Littman, D. R.; Dustin, M. L.; Gan, W. B., (2005) ATP mediates rapid microglial response to local brain injury in vivo. Nat Neurosci 8 (6), 752-8.

(35) Honda, S.; Sasaki, Y.; Ohsawa, K.; Imai, Y.; Nakamura, Y.; Inoue, K.; Kohsaka, S., (2001) Extracellular ATP or ADP induce chemotaxis of cultured microglia through Gi/o-coupled P2Y receptors. J Neurosci 21 (6), 1975-82.

(36) Bonhaus, D. W.; Flippin, L. A.; Greenhouse, R. J.; Jaime, S.; Rocha, C.; Dawson, M.; Van Natta, K.; Chang, L. K.; Pulido-Rios, T.; Webber, A.; Leung, E.; Eglen, R. M.; Martin, G. R., (1999) RS-127445: a selective, high affinity, orally bioavailable 5-HT2B receptor antagonist. Br J Pharmacol 127 (5), 1075-82.

(37) Rebsam, A.; Petros, T. J.; Mason, C. A., (2009) Switching retinogeniculate axon laterality leads to normal targeting but abnormal eye-specific segregation that is activity dependent. J Neurosci 29 (47), 14855-63.

(38) Young, T. R.; Bourke, M.; Zhou, X.; Oohashi, T.; Sawatari, A.; Fässler, R.; Leamey, C. A., (2013) Ten-m2 is required for the generation of binocular visual circuits. $J$ Neurosci 33 (30), 12490-509.

(39) Mallat, M.; Marin-Teva, J. L.; Cheret, C., (2005) Phagocytosis in the developing CNS: more than clearing the corpses. Curr Opin Neurobiol 15 (1), 101-7.

(40) Meltzer, H. Y.; Massey, B. W., (2011) The role of serotonin receptors in the action of atypical antipsychotic drugs. Curr Opin Pharmacol 11 (1), 59-67.

(41) Livak, K. J.; Schmittgen, T. D., (2001) Analysis of relative gene expression data using real-time quantitative PCR and the 2(-Delta Delta C(T)) Method. Methods 25 (4), 4028.

(42) Gervasi, N.; Hepp, R.; Tricoire, L.; Zhang, J.; Lambolez, B.; Paupardin-Tritsch, D.; Vincent, P., (2007) Dynamics of protein kinase A signaling at the membrane, in the cytosol, and in the nucleus of neurons in mouse brain slices. J Neurosci 27 (11), 274450 . 


\section{Figure 1}

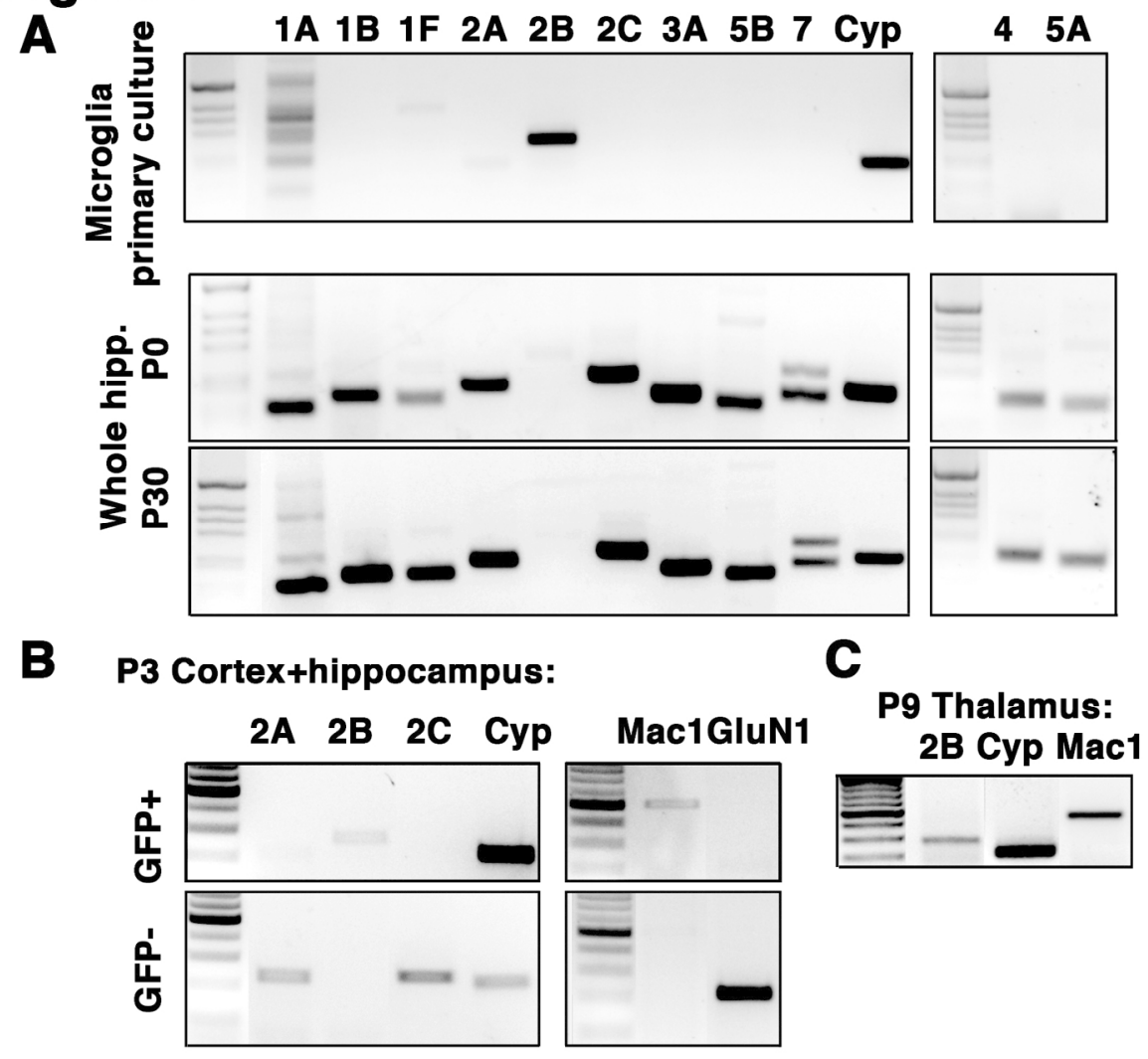

D P9 Cortex+hippocampus: $\quad$ P9 Brain Stem:

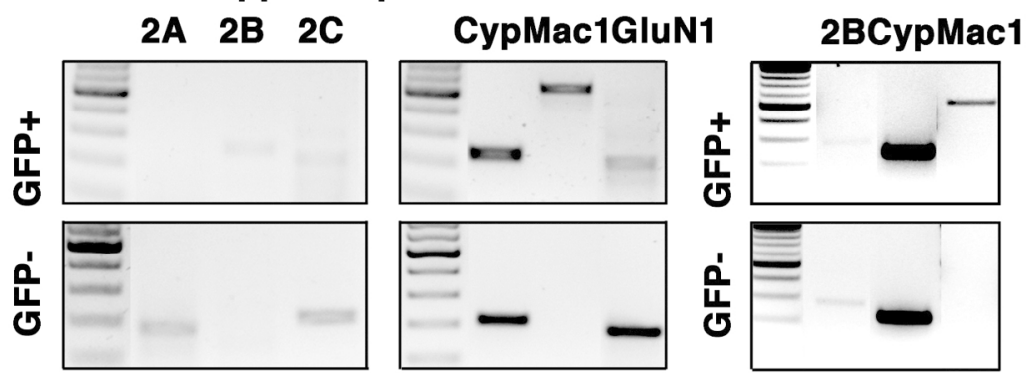

149×189mm (300 x 300 DPI) 


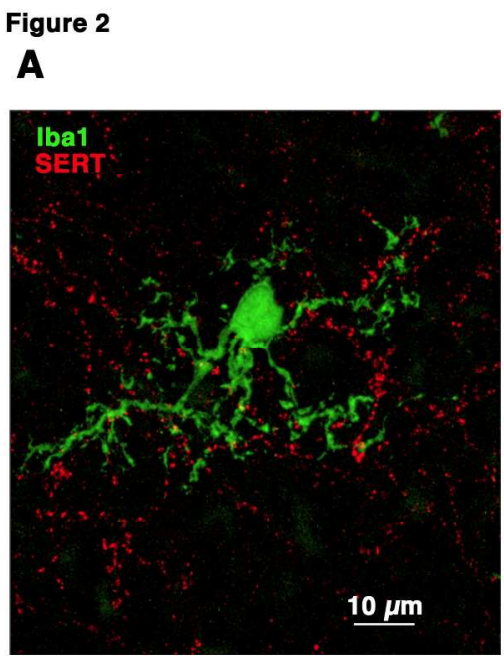

B
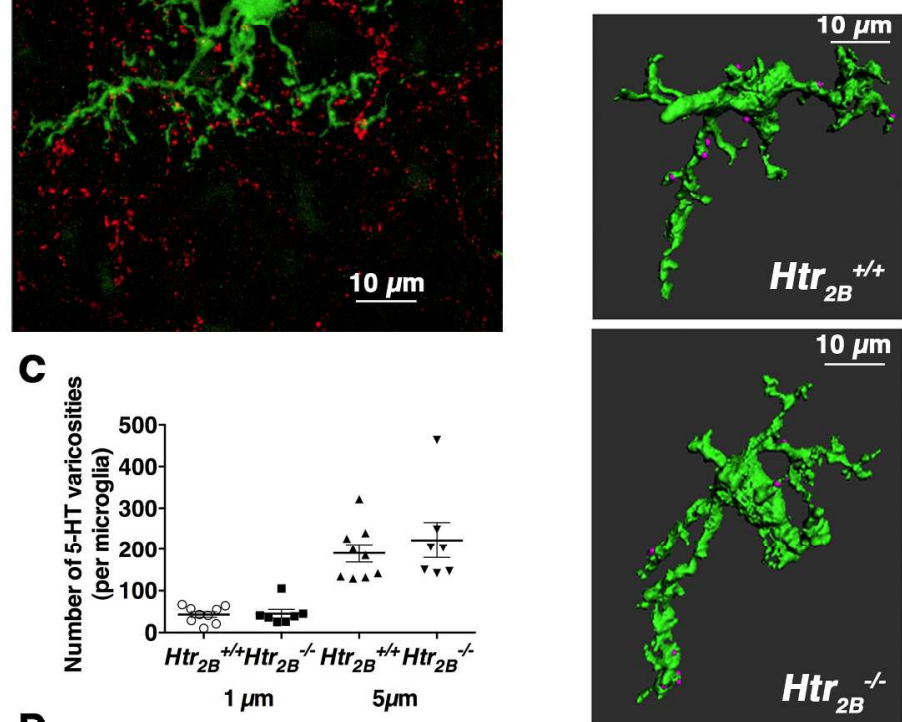

$10 \mu \mathrm{m}$
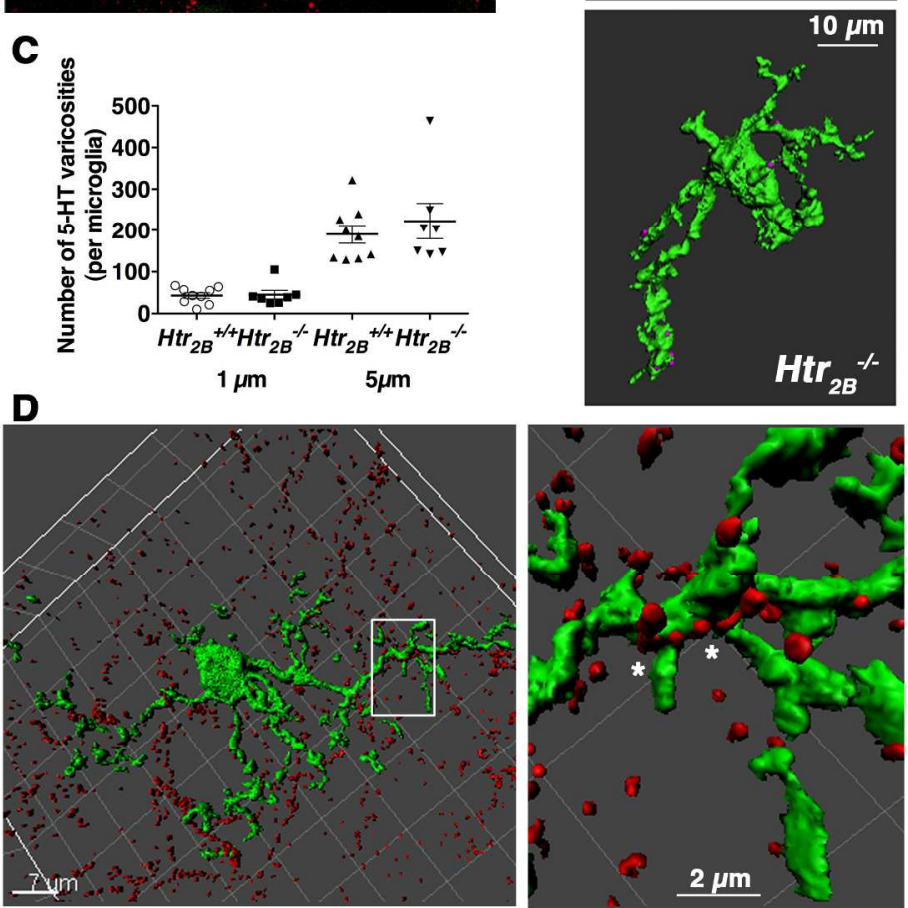

$154 \times 258 \mathrm{~mm}(300 \times 300$ DPI $)$

49

50

51

52

53

54

55

56 


\section{Figure 3}

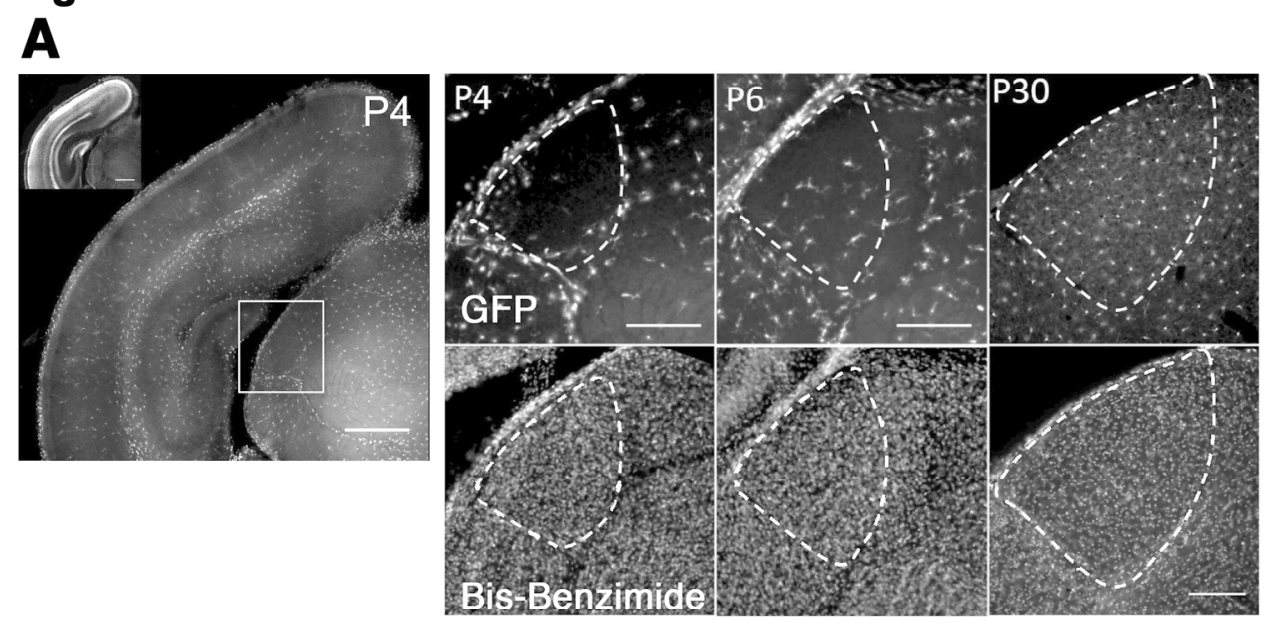

B

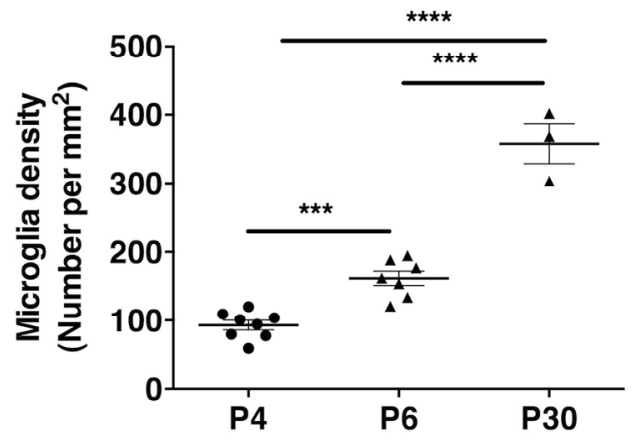

C

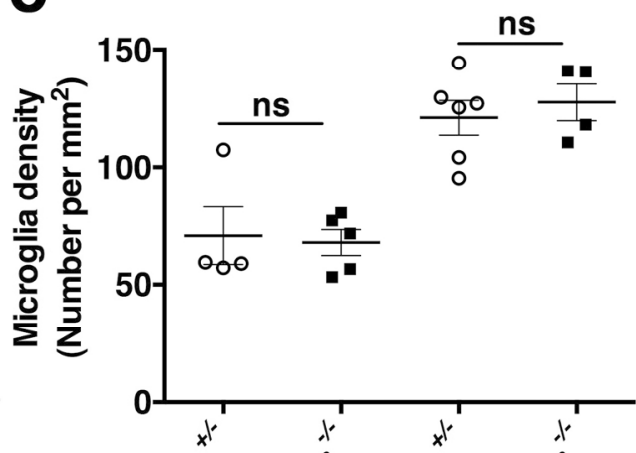

$175 \times 174 \mathrm{~mm}(300 \times 300$ DPI $)$ 
Figure 4

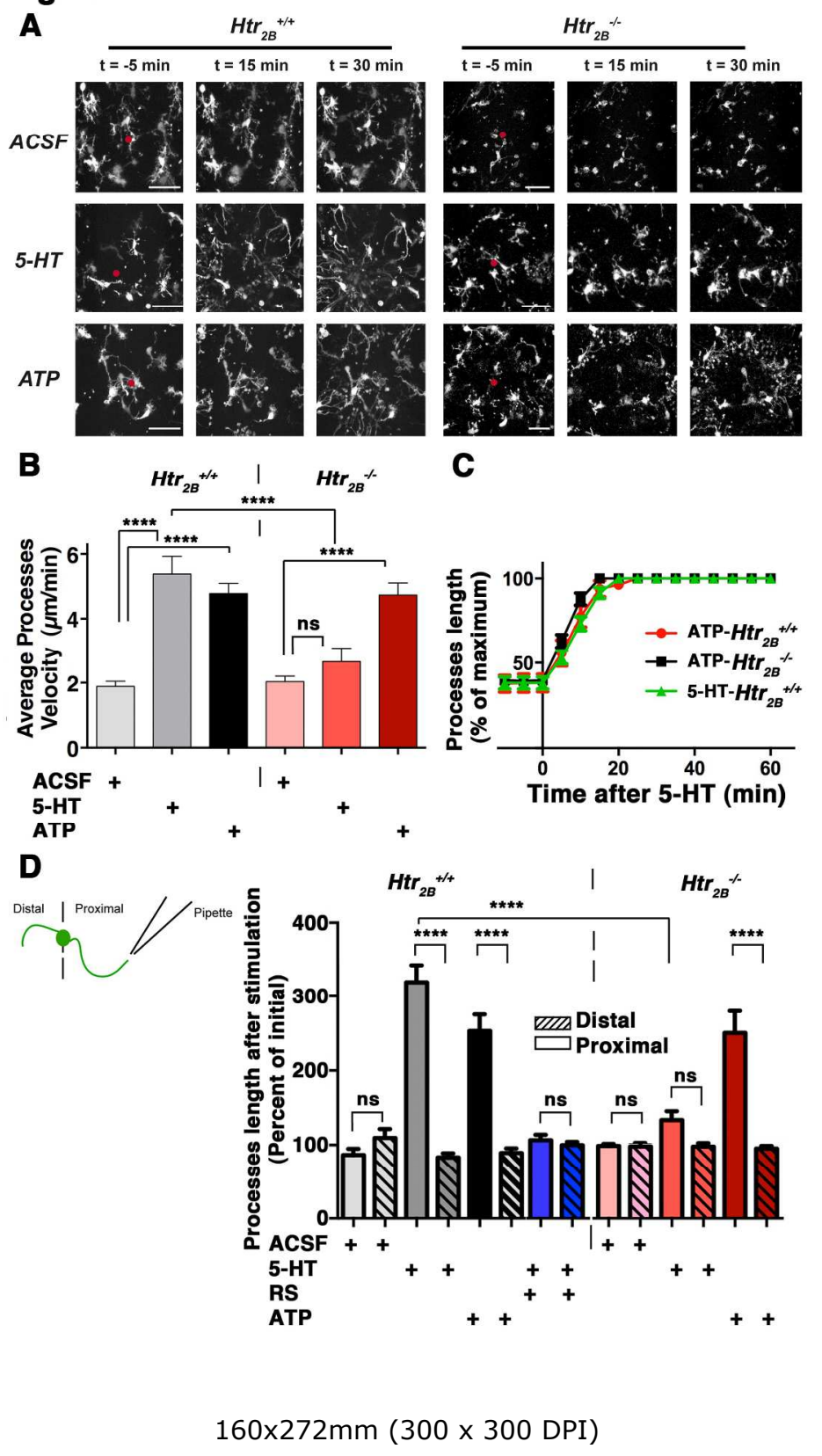


Figure 5
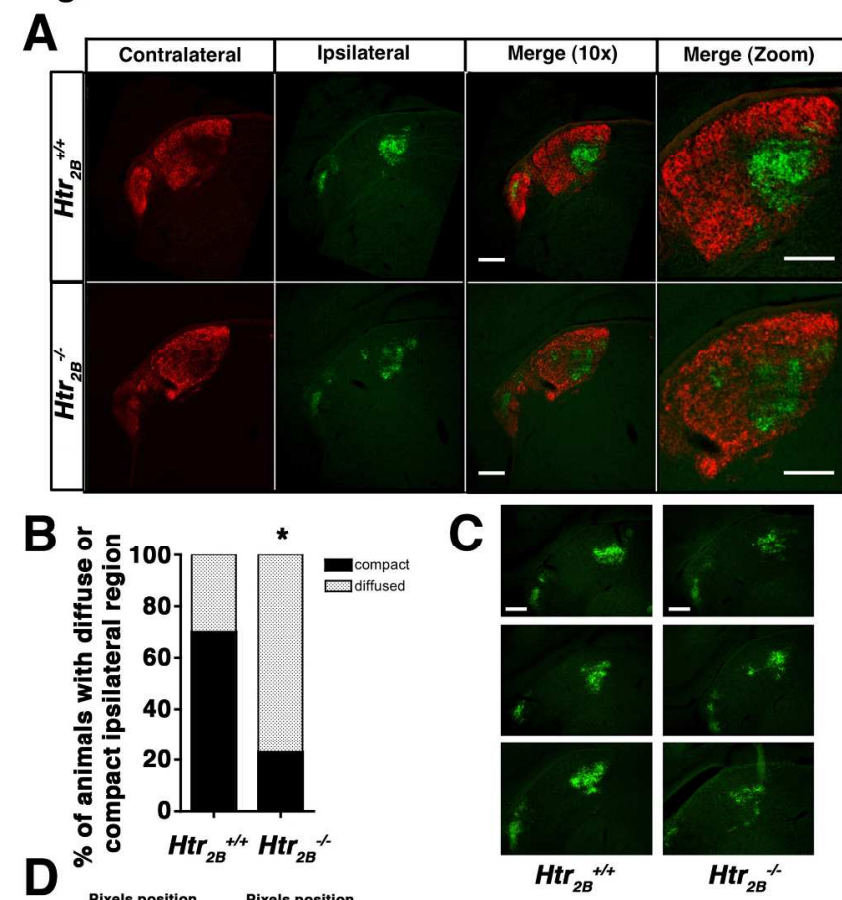

C
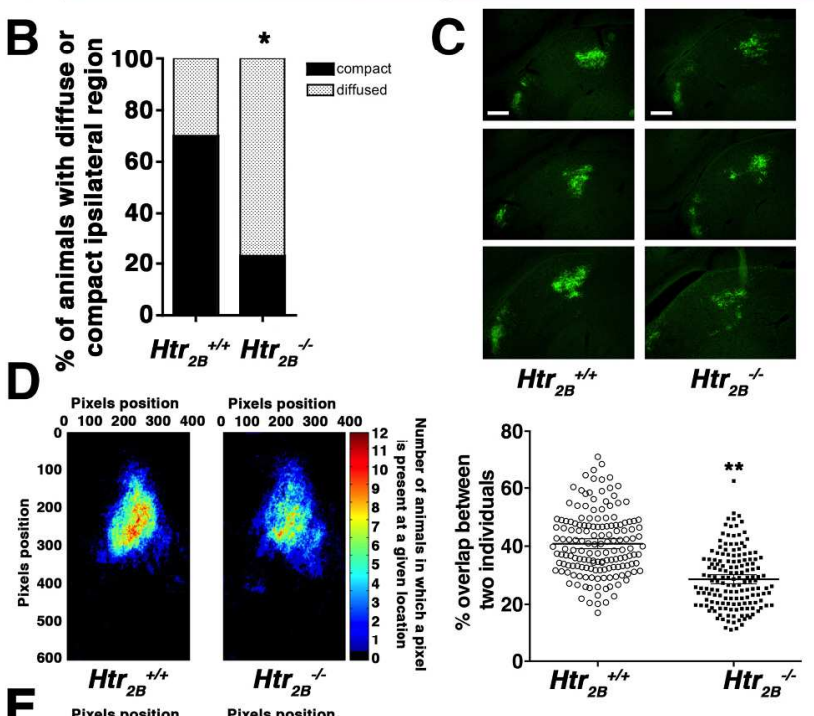

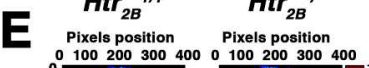
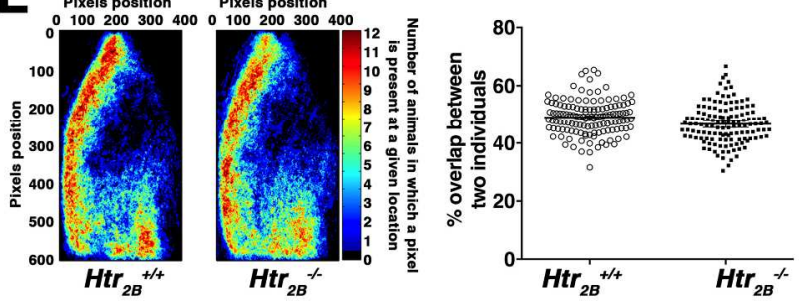

$148 \times 270 \mathrm{~mm}(300 \times 300$ DPI $)$ 


\section{Figure 6}
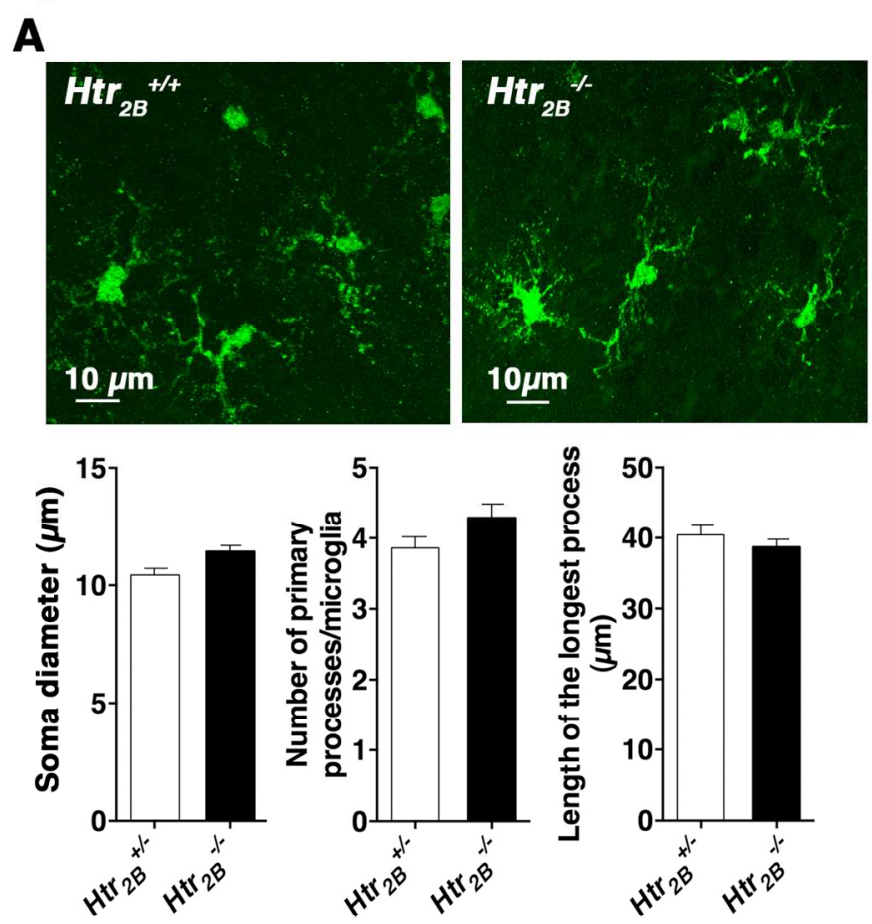

B

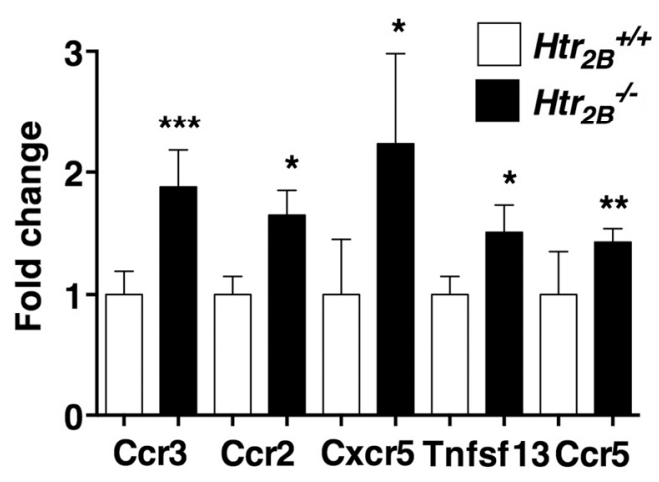

$104 \times 180 \mathrm{~mm}(300 \times 300 \mathrm{DPI})$ 


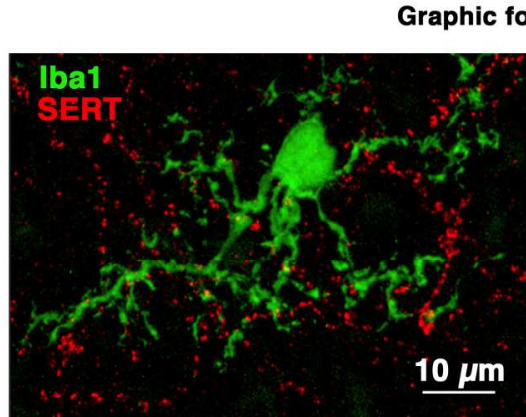

Microglial processes and serotonergic axons are found in close contact
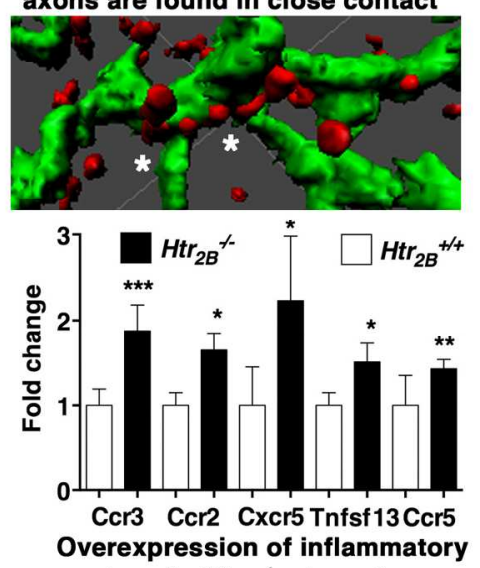
markers in $\mathrm{Htr}_{2 \mathrm{~B}}{ }^{-1}$ microglia

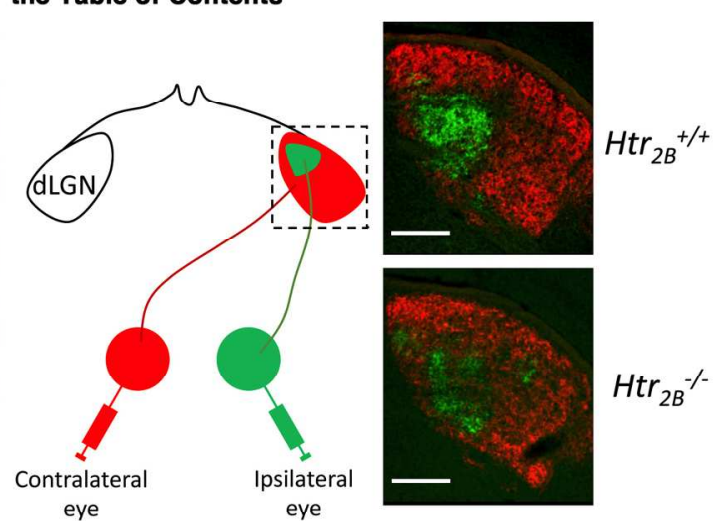

Defects in synaptic refinement in $\mathrm{Htr}_{2 B}{ }^{-{ }^{-}}$mice

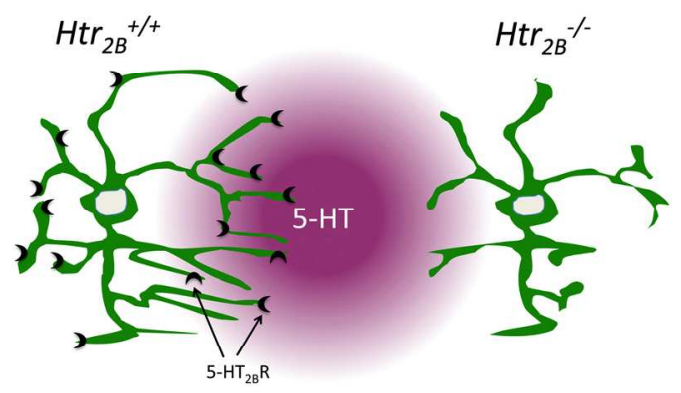

Lack of microglial processes chemoattraction to serotonin in $\mathrm{Htr}_{2 \mathrm{~B}}{ }^{-1}$ mice

$180 \times 150 \mathrm{~mm}(300 \times 300 \mathrm{DPI})$ 